\title{
Ecosystem services provided by waterbirds
}

\author{
Andy J. Green ${ }^{1, *}$ and Johan Elmberg ${ }^{2}$ \\ ${ }^{1}$ Department of Wetland Ecology, Estación Biológica de Doñana, CSIC, E-41092 Sevilla, Spain \\ ${ }^{2}$ Division of Natural Sciences, Kristianstad University, SE-291 88 Kristianstad, Sweden
}

\begin{abstract}
Ecosystem services are ecosystem processes that directly or indirectly benefit human well-being. There has been much recent literature identifying different services and the communities and species that provide them. This is a vital first step towards management and maintenance of these services. In this review, we specifically address the waterbirds, which play key functional roles in many aquatic ecosystems, including as predators, herbivores and vectors of seeds, invertebrates and nutrients, although these roles have often been overlooked. Waterbirds can maintain the diversity of other organisms, control pests, be effective bioindicators of ecological conditions, and act as sentinels of potential disease outbreaks. They also provide important provisioning (meat, feathers, eggs, etc.) and cultural services to both indigenous and westernized societies. We identify key gaps in the understanding of ecosystem services provided by waterbirds and areas for future research required to clarify their functional role in ecosystems and the services they provide. We consider how the economic value of these services could be calculated, giving some examples. Such valuation will provide powerful arguments for waterbird conservation.
\end{abstract}

Key words: bioindicators, cultural services, economic value, ecosystem engineering, ecosystem services, nutrient fluxes, pest control, seed dispersal, waterfowl harvest, zoochory.

\section{CONTENTS}

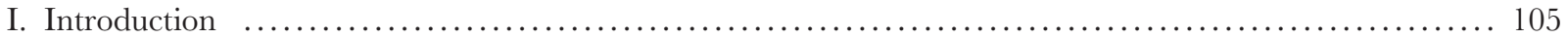

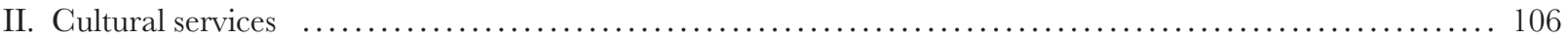

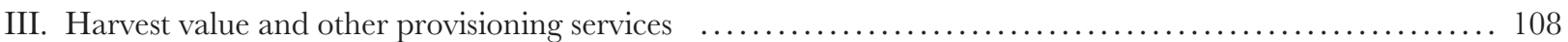

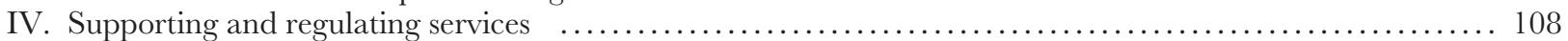

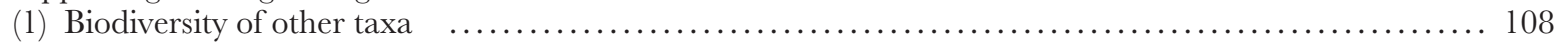

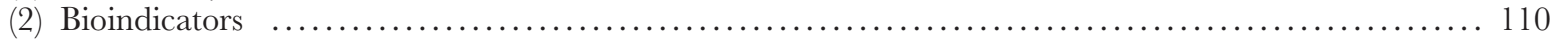

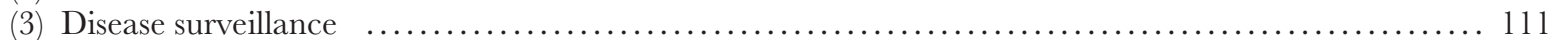

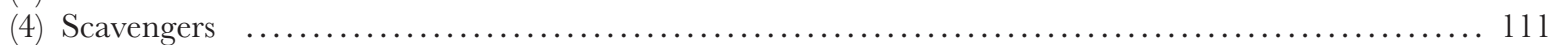

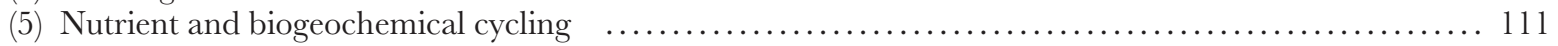

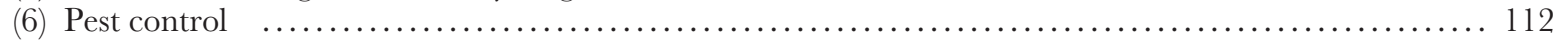

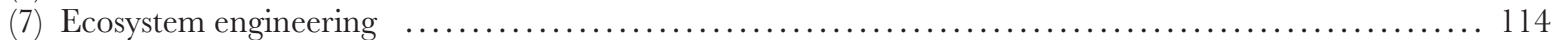

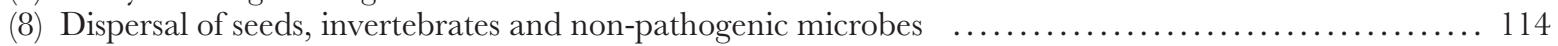

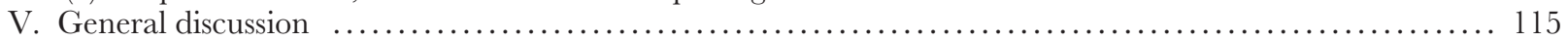

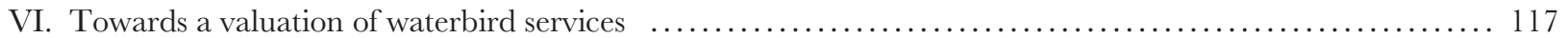

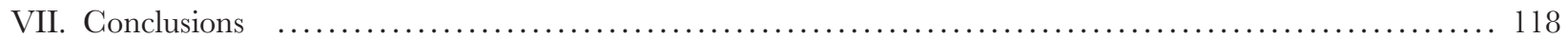

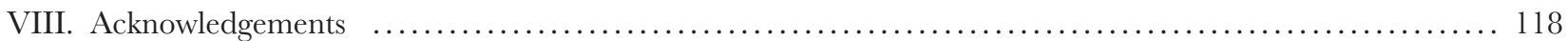

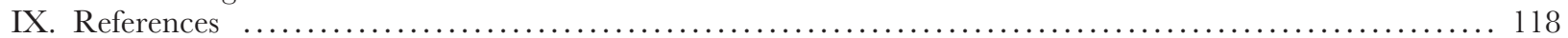

\section{INTRODUCTION}

The term 'ecosystem services' is increasingly used to describe ecosystem resources and processes that have a benefit to human society, particularly since its popularization by the
Millennium Ecosystem Assessment (MEA) (2005). If we can identify such services and quantify their value, we can argue more effectively for the protection of ecosystems and the species within them, and so influence public opinion and policy decisions (Daily et al., 2009). As recently pointed out

* Address for correspondence (E-mail: ajgreen@ebd.csic.es). 
by Wenny et al. (2011), there is an urgent need to further the understanding of what ecosystem services are provided by birds, and to establish methodologies for quantifying their value. Although these authors provide an excellent review of the different services carried out by birds and progress to date in estimating their value (see also Whelan, Wenny $\&$ Marquise, 2008), they focus on terrestrial birds. In this paper we focus exclusively on waterbirds (sensu Wetlands International, 2012, including all aquatic birds such as Anatidae, shorebirds, rails, wading birds, gulls and terns) and aim to complement existing work by reviewing how waterbirds provide the service categories identified by the above authors, as well as by identifying additional services. In doing so, we highlight ecosystem services that are unique for waterbirds, and which are powerful arguments for their conservation.

Ultimately, terrestrial and aquatic systems are strongly interdependent, as shown by a growing body of research (Nakano \& Murakami, 2001; Burdon \& Harding, 2008). Nevertheless, it is important to consider explicitly the role of waterbirds in subsidies between aquatic and terrestrial ecosystems. Furthermore, ecosystem service research is in its infancy and is largely proceeding on a case by case basis at the scale of individual sites (Luck et al., 2009), making it practical to address the services provided by waterbirds in and around a specific lake or other wetland. There is obviously much to be learned and gained by considering the role of birds in freshwater and wetland habitats. In this review we make the point that there are many ways in which waterbirds provide a service, but also highlight numerous areas in which our understanding of the functional role of waterbirds remains very limited. We make proposals for further research required to clarify the importance of the services provided by waterbirds, and the role of different species, in the hope that this will stimulate others.

Ecosystem services provided by wetlands have been relatively well studied and their value has been estimated in an increasing number of cases (MWO, 2012). Wetland services include water purification, fixation of run-off nutrients, flood prevention, aquifer recharge and fishery maintenance. By contrast, the specific role of waterbirds within aquatic ecosystems has often been overlooked. In our view this is largely owing to a shortage of interdisciplinary research between ornithologists and aquatic ecologists or limnologists. Birds are surprisingly often excluded from models of aquatic food webs (Mooij et al., 2007; van Nes, Rip \& Scheffer, 2007), or perceived as only reacting to the 'bottom-up' influence of fish, vegetation or other organisms, without having any 'top-down' influence themselves (e.g. Janse, 1997; Scheffer et al., 2006). Sometimes birds are not even mentioned in aquatic ecology textbooks (Lampert \& Sommer, 2007). On the other hand, the extensive literature on North American waterfowl is focused principally on how to create suitable conditions so as to guarantee a hunting resource, with little or no attention to other ecological services provided by those populations. In this review we will cite numerous cases that testify to the unique and often central role of waterbirds in many aquatic ecosystems and to the importance of the services they provide.

The profound impact of seabirds on island ecosystems by depositing nutrients of marine origin and via ecosystem engineering is now clearly recognized (Fukami et al., 2006; Sekercioglu, 2006). The present review focuses on waterbirds using inland waterbodies and estuaries, and does not explicity cover seabirds, although many bird species use both marine and inland aquatic ecosystems during different stages of the life cycle, and there is overlap in the services provided by each group. Our aim is to concentrate on the positive ecological consequences of waterbirds, rather than on the negative ones or 'ecological disservices' (Dunn, 2010). Disservices such as transmission of diseases that can potentially affect humans (Hubalek, 2004), or conflicts with fisheries (Carss \& Marzano, 2005; Harris et al., 2008), are dealt with adequately by existing literature and do not require further review here. However, we point out other, less well-known, disservices below without reviewing them at length. All kinds of disservices must be taken into account to evaluate the 'net contribution' of waterbirds.

Ecosystem services are generally divided into four categories (Table 1; Millennium Ecosystem Assessment, 2005). Many of the services provided by waterbirds are 'supporting services' such as propagule dispersal or nutrient cycling, which are processes vital to ecological communities and agricultural or fishery ecosystems. Others are 'regulating services' such as pest control, or 'provisioning services', which apply to resources directly exploited for food, clothing or other uses. Finally there are 'cultural services', which apply to the recreational value or spiritual value of birds. However, in the case of waterbirds this 'fourbox' terminology cannot be applied in a straightforward manner, as services frequently overlap and interact among categories. For example, waterbird hunting for subsistence is a provisioning service, but at the same time in many cultures waterbird hunting is a cultural service with recreational or spiritual value (e.g. as indicated by Figs 1, 2). We therefore do not refer consistently to this categorization.

\section{GULTURAL SERVICES}

Anatidae and other waterbirds have a major cultural value in many parts of the world (Kear, 1990). Ducks also have important amenity values for the human population, both in rural (van Kooten, Withey \& Wong, 2011) and urban landscapes. In modern times, the human interest in seeing concentrations of waterfowl on migration or at wintering sites (Fig. 3) has facilitated the protection of many of these sites and ultimately led to the initiative to establish the Ramsar Convention (Convention on Wetlands) in 1971 as well as non-governmental organizations such as The Wildfowl \& Wetlands Trust (UK) and Wetlands International (originally The International Waterfowl Research Bureau). Ducks, geese, swans, flamingoes and other waterbirds are used as flagships of conservation in general; the wide public 
Table 1. Selected examples of ecosystem services provided by waterbirds

\begin{tabular}{|c|c|c|c|}
\hline Category & Ecosystem service & Waterbird taxon & References \\
\hline \multirow[t]{4}{*}{ Provisioning } & Meat & Anatidae & Krcmar et al. (2010) \\
\hline & Down & Common eider, geese & Sveinsson 2013; and Kear (1990) \\
\hline & Feathers for clothing and ornaments & Anatidae, herons, others & Green \& Figuerola (2005) and Frisch et al. (2007) \\
\hline & Grease for waterproofing & Geese & MacMillan \& Leader-Williams (2008) \\
\hline \multirow[t]{12}{*}{ Supporting } & Animal propagule dispersal & Anatidae, coots & Green \& Figuerola (2005) and Frisch et al. (2007) \\
\hline & Plant propagule dispersal & Anatidae, shorebirds & $\begin{array}{l}\text { Green et al. }(2002 b) \text {, Klein et al. (2008) and Brochet } \\
\text { et al. (2009) }\end{array}$ \\
\hline & Nutrient cycling & Geese, cormorants & $\begin{array}{l}\text { (Iacobelli \& Jefferies, 1991), Gauthier et al. (2006) and } \\
\text { Kameda et al. (2006) }\end{array}$ \\
\hline & Stimulating primary productivity & Geese & $\begin{array}{l}\text { (Cargill \& Jefferies, 1984), Bazely \& Jefferies (1985) } \\
\text { and Nolet (2004) }\end{array}$ \\
\hline & Stimulating decomposition & Ducks & Bird et al. (2000) and van Groenigen et al. (2003) \\
\hline & Reduction of methane production & Swans & Bodelier et al. (2006) \\
\hline & Plant diversity & Anatidae & $\begin{array}{l}\text { Maron et al. (2006), Jasmin et al. (2008) and Hidding } \\
\text { et al. (2010) }\end{array}$ \\
\hline & Animal diversity & Anatidae, others & $\begin{array}{l}\text { Fabricius \& Norgren (1987) and Georgiev et al. (2005, } \\
\text { 2007) }\end{array}$ \\
\hline & Protection from predators & Geese & $\begin{array}{l}\text { Fabricius \& Norgren (1987) and Allard \& Gilchrist } \\
\text { (2002) }\end{array}$ \\
\hline & Bioindicators of plants & Anatidae, coots & $\begin{array}{l}\text { Elmberg et al. (1993), Wicker \& Endres (1995) and } \\
\text { Green } \text { et al. (2002a) }\end{array}$ \\
\hline & Bioindicators of animals & Anatidae & $\begin{array}{l}\text { Elmberg et al. }(1993,2010) \text { and Gunnarsson et al. } \\
\text { (2004) }\end{array}$ \\
\hline & Bioindicators of nutrients/contaminants & Herons, grebes, ducks & $\begin{array}{l}\text { Fasola et al. (1998), Nummi et al. (2000) and Burger \& } \\
\quad \text { Eichhorst (2007) }\end{array}$ \\
\hline \multirow[t]{3}{*}{ Regulating } & Pest control & Ducks & $\begin{array}{l}\text { Hamilton et al. (1994), Teo (2001) and Miles et al. } \\
\text { (2002) }\end{array}$ \\
\hline & Disease surveillance & Ducks & $\begin{array}{l}\text { Munster et al. (2005), Wallensten et al. (2007) and } \\
\text { Ziegler et al. (2010) }\end{array}$ \\
\hline & Regime shifts of wetlands & Cormorants & Leah et al. (1980) and Dirksen et al. (1995) \\
\hline \multirow[t]{5}{*}{ Cultural } & Recreational hunting & Anatidae & $\begin{array}{l}\text { Losey \& Vaughan (2006), Grado et al. (2011) and } \\
\quad \text { Withey \& van Kooten (2011) }\end{array}$ \\
\hline & Birdwatching & Geese & MacMillan \& Leader-Williams (2008) \\
\hline & Ecotourism & Geese & Edgell \& Williams (1992) \\
\hline & Conservation flagships & Anatidae, flamingoes & Kear (1990) and Galicia \& Baldassarre (1997) \\
\hline & Art & Flamingoes, others & Mas (2000) and Arnott (2007) \\
\hline
\end{tabular}

'Category' refers to the standard classification as outlined by the Millennium Ecosystem Assessment (2005). A maximum of three references is given per example. The waterbird taxa correspond to the studies cited, other taxa are also likely to provide the same service.

interest in them has led to a greater awareness of conservation issues and promoted action to protect populations, species and their habitats. As a small child, the first author was inspired to think about global conservation by a poster about flamingoes at Lake Nakuru on his bedroom wall. These flagships have in turn benefited other wetland species for which awareness and public support have generally been much lower. For example, most of the 2087 wetlands around the world declared as Ramsar sites (collectively protecting 204803109 ha of habitat, http://www.ramsar.org/) were declared using criteria based on their importance for waterbirds.

Larger waterbirds are particularly important for cultural services. Humans clearly feel a special reverence for birds such as swans, flamingos and ibises for example, as reflected through their artistic and religious importance through history (e.g. association between royalty and swans in the UK, Fig. 4, or the African sacred ibis Threskiornis aethiopicus in Ancient Egypt). Greater flamingoes Phoenicopterus roseus are represented in Palaeolithic cave art from southern Spain (Mas, 2000). Arnott (2007) cited numerous examples of waterbirds in ancient art. Feathers from waterbirds such as herons, terns and grebes became highly prized for fashion items in the 19th century, leading to overhunting of these birds and ultimately to the birth of bird conservation organizations (Doughty, 1975). The economic benefits from cultural services are important, although they have rarely been quantified. Contingent valuation was used to estimate the extent to which the human population values goose populations in Scotland, and found that the economic benefits of goose conservation outweighed the costs resulting from agricultural conflicts (crop damage) by a factor of up to 700 (MacMillan, Hanley \& Daw, 2004). Goose-related tourism has been shown to play a vital role in the local economy of the Scottish island of Islay (Edgell \& Williams, 1992). However, for the purposes of this review we are 


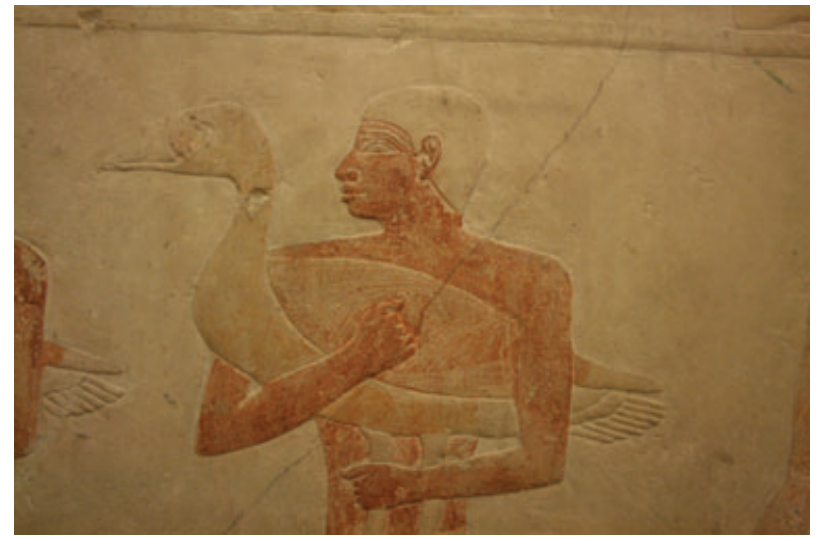

Fig. 1. One of three figures holding harvested geese on the decoration of the Tomb of Akhethetep from Saqqara in ancient Egypt (fifth dynasty, c. 2400 BC), now in the Louvre in Paris (see layout of the tomb at http://www.insecula.com/ oeuvre/photo_ME0000036922.html). Many other images of goose harvest are found in the Egyptian section of the Louvre. Photograph: David Stroud.

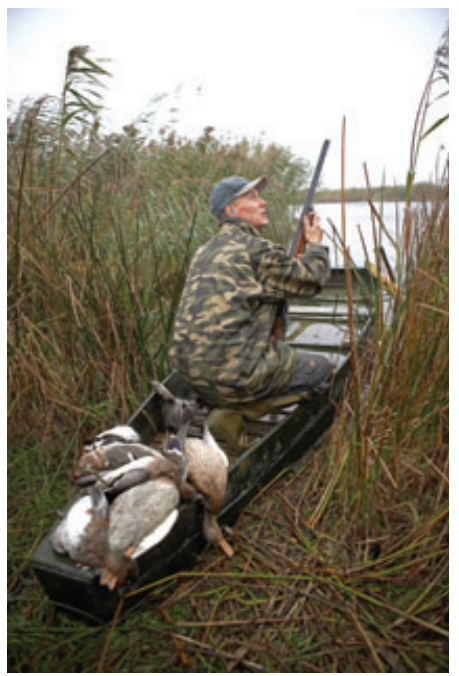

Fig. 2. Duck hunting in Sweden. Waterbirds have provided a provisioning service via hunting throughout history, and the modern economic benefits are a powerful force for wetland management and conservation. Photograph: Sten Christoffersson.

concerned primarily with the ecological role of birds, and we will not consider these cultural services in further detail (but see Kear, 1990).

\section{HARVEST VALUE AND OTHER PROVISIONING SERVICES}

Anatidae, Rallidae, shorebirds and other waterbirds are harvested for human consumption the world over (Figs 1, 2). For example, waterfowl are a major part of the diet of indigenous people at high latitudes in North
America (Krcmar, van Kooten \& Chan-McLeod, 2010). The economic value of harvest has been quantified in several studies (Table 2). An estimated $\$ 1.5$ billion was spent on waterfowl hunting in the USA in 1996 alone (Losey \& Vaughan, 2006). In the state of Mississippi, the total economic impact of waterfowl hunting has been valued at $\$ 155$ million (2010 USD) a year (Henderson et al., 2010). Withey \& van Kooten (2011) estimated the value of each duck hunted in Canada as \$26. The economic values of duck hunting are such that the economic benefits of conserving natural prairie wetlands in North and South Dakota owing to greater duck production are considered to outweigh the benefits of converting to cropland (Gascoigne et al., 2011).

In the European Union, there are more than 6.7 million hunters (Mooij, 2005), which is more than the number of inhabitants in many of its member states. Together, EU hunters shoot at least 7.6 million waterfowl and 4.2 million shorebirds and gulls annually (Hirschfeld \& Heyd, 2005). In parts of northern Europe (e.g. southern Sweden) arable land has been converted to wetlands for the purpose of waterfowl hunting in the last decades, because the value of waterfowl harvest and ecotourism is greater than that of traditional farming. Although the economic value of waterfowl hunting has not been quantified in many parts of Europe, visitor expenditure by goose hunters in Scotland in 1997-1998 was estimated as 40\% greater than expenditure by the considerable number of birdwatchers watching geese (MacMillan \& Leader-Williams, 2008).

'Harvest' represents more than just killing birds for meat consumption. Picking eggs of ducks and geese for consumption was historically commonplace in many countries, as was use of their feathers for arrow flights and their grease for waterproofing, lubrication, as ointments and as oil for lamps (MacMillan \& Leader-Williams, 2008). Although eggs may still be an important source of protein in poor countries and to some indigenous peoples, this habit is nowadays much rarer or prohibited in most industrialized countries owing to the widespread availability of hens' eggs. Another important provisioning service by waterfowl is the use of down and other feathers for bedding and insulation. Today much of the latter stem from farmed geese, but historically down from wild eider ducks Somateria mollissima was highly prized. Nowadays, most eider down is harvested in Iceland, and the annual retail value of goods made from this down has been estimated at $\$ 40$ million (Sveinsson, 2013)

\section{SUPPORTING AND REGULATING SERVICES}

\section{(1) Biodiversity of other taxa}

In multiple ways, the presence and activity of waterbirds can have profound positive effects on aquatic biodiversity. For example, they are major vectors of dispersal with a crucial role in maintaining general diversity of isolated or ephemeral wetlands by the spread of plant and animal propagules. 


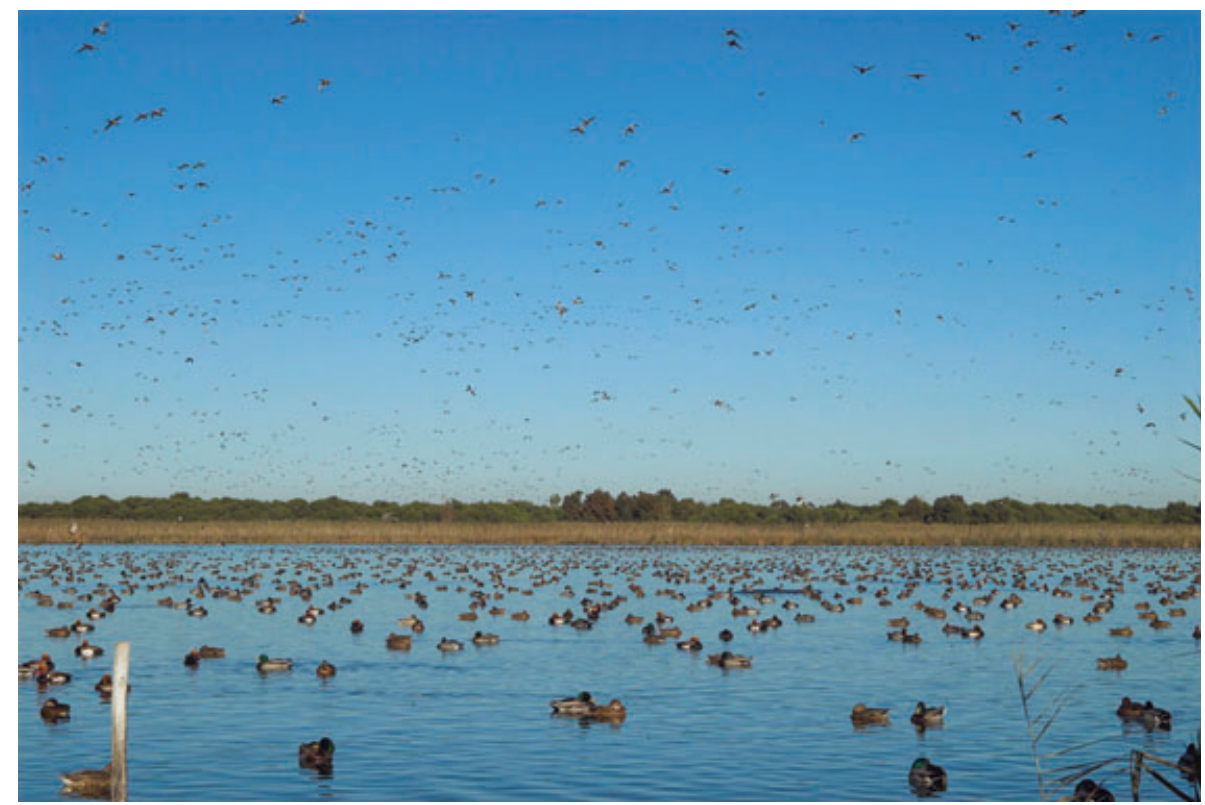

Fig. 3. Ducks wintering in the Albufera de Valencia, eastern Spain. Such wintering concentrations can provide a spectacle for the public (i.e. a cultural service), an opportunity for controlled harvest (a provisioning service) and strong nutrient cycling (supporting service). Photograph: Carlos Oltra.

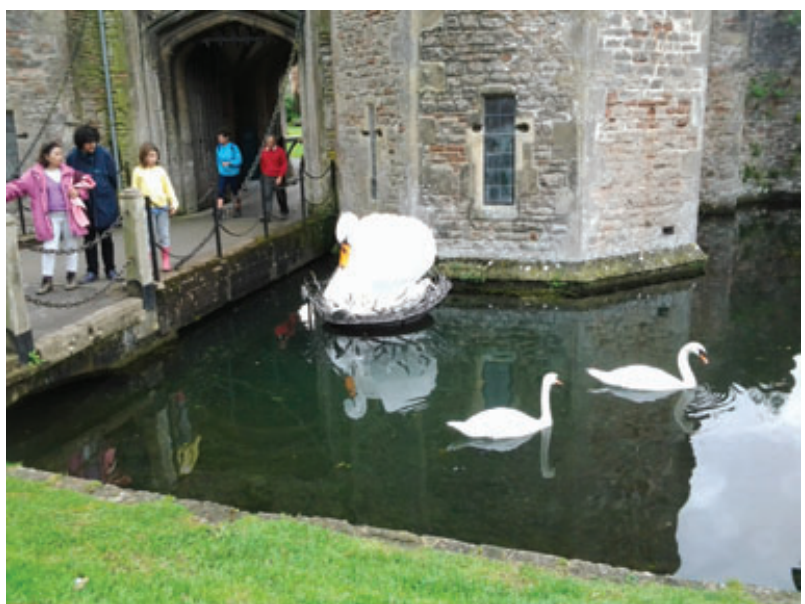

Fig. 4. An example of a cultural service. Two mute swans Cygnus olor are accompanied by 1 of 60 swan sculptures made in Wells, England to commemorate the Queen's jubilee in 2012. People have a particular affection for swans and other large waterbirds. Photograph: Andy J. Green.

This is a multiscale service, upholding biodiversity locally, regionally and even at continental scales (see Section IV.8).

Geese can play a vital role in maintaining grasslands in a natural state of high diversity, notably by promoting coexistence of different plant species by regulating interspecific competition (Jasmin, Rochefort \& Gauthier, 2008), and by stimulating primary production (Cargill \& Jefferies, 1984; Bazely \& Jefferies, 1985). The elimination of the Aleutian cackling goose Branta hutchinsii leucopareia by introduced foxes is thought to have contributed to the low diversity of plants in the Aleutian Islands (Maron et al., 2006), owing to release from grazing pressure. Grazing by waterfowl can also increase the diversity of submerged macrophytes (Hidding et al., 2010), as well as their productivity (Nolet, 2004). Grazing on seagrasses by geese and wigeon Anas penelope can have a positive long-term effect on seagrass beds due to reduced mud accretion in grazed beds (Nacken \& Reise, 2000). Similarly, grazing by swans on water crowfoot Ranunculus penicillatus pseudofluitans in chalk streams may potentially increase the survival of this plant over winter, since grazing reduces resistance to high winter flows that cause uprooting (Wood et al., 2012). However, excessive grazing by geese can lead to soil erosion, soil salinization, loss of soil nitrogen retention, and other negative effects (Iacobelli \& Jefferies, 1991; Gauthier, Giroux \& Lochefort, 2006; Buckeridge \& Jefferies, 2007). For example, the recovery of Aleutian cackling geese is thought to have led to soil erosion and burrow collapse in a seabird colony in California, where the geese stage in spring (Mini et al., 2011). Furthermore, feral geese populations can favour the spread of alien grasses, even when they selectively graze on those same grasses (Best \& Arcese, 2009: Isaac-Renton et al., 2010).

Waterbirds can provide protection from predators for other taxa. For example, Canada geese Branta canadensis defend their nests strongly against potential predators, and other birds nesting in their vicinity enjoy a higher breeding success (Allard \& Gilchrist, 2002). This defence effect may also carry over to the community level; in some Swedish archipelagoes species richness of nesting birds is higher on islets with nesting Canada geese than on neighbouring islets without (Fabricius \& Norgren, 1987). Mann, Proctor \& Taylor (1999) suggested that predation of herbivorous 
Table 2. Examples of valuation of provisioning and cultural services by waterbirds

\begin{tabular}{|c|c|c|c|}
\hline Taxon & Valuation & Method & References \\
\hline Migratory birds & $\begin{array}{l}\$ 1.5 \text { billion spent in the US on hunting } \\
\text { in } 1996\end{array}$ & Actual expenditure & Losey \& Vaughan (2006) \\
\hline Whooping crane Grus americana & $\begin{array}{l}\text { Each US household willing to pay } \$ 56 \\
(2006) \text { per year to save the species }\end{array}$ & Contingent valuation & Richardson \& Loomis (2009) \\
\hline Ducks & $\begin{array}{l}\$ 320 \text { million }(2008) \text { spent hunting per } \\
\text { year in USA, \$26 per duck harvested }\end{array}$ & Actual expenditure & Withey \& van Kooten (2011) \\
\hline Ducks and geese & $\begin{array}{l}\$ 763 \text { (1991) mean expenditure per year } \\
\text { by Louisiana hunters }\end{array}$ & Actual expenditure & Gan \& Luzar (1993) \\
\hline Ducks and geese & $\begin{array}{l}\$ 155 \text { million }(2010) \text { generated by } \\
\text { hunting in Mississippi, including } \\
1898 \text { jobs created }\end{array}$ & Total economic impact & Henderson et al. (2010) \\
\hline Geese & $\begin{array}{l}\mathcal{E}^{1.5} \text { million (1998) per year spent on } \\
\text { goose watching and } \AA^{2.1} \text { million on } \\
\text { hunting in Scotland }\end{array}$ & Actual expenditure & MacMillan \& Leader-Williams (2008) \\
\hline $\begin{array}{l}\text { Greenland white-fronted Anser } \\
\text { albifrons and barnacle geese } \\
\text { Branta leucopsis }\end{array}$ & $\begin{array}{l}\text { Scottish population willing to pay } £^{35} \\
\text { million to secure a } 10 \% \text { rise in goose } \\
\text { numbers }\end{array}$ & Contingent valuation & MacMillan et al. (2004) \\
\hline Eider Somateria mollissima & $\begin{array}{l}\text { Annual down harvest in Iceland used to } \\
\text { produce } \$ 40 \text { million worth of retail } \\
\text { goods }\end{array}$ & Unknown & Sveinsson (2013) \\
\hline
\end{tabular}

invertebrates in shallow ponds by shorebirds allows the persistence of charophyte species (e.g. Tolypella glomerata) that lack resistance to herbivory.

Waterbirds themselves can be considered as "ecosystems" in that they act as hosts for a wide variety of parasites and commensalists, often specific to a small number of bird species, including an unknown number of parasite species yet to be described. In some cases, the presence of these parasites makes a major contribution to the total biodiversity in aquatic ecosystems, as illustrated by endoparasites with complex life cycles that use invertebrates or fish as intermediate hosts. For example, hypersaline salt ponds and lakes have unusually low invertebrate species richness and are often dominated by brine shrimp Artemia spp. as the main macroinvertebrate (Sánchez, Green \& Castellanos, 2006). However, a diverse community of waterbirds preying on the shrimps maintains up to 15 species of cestodes within the Artemia population, each using a specific waterbird group as final hosts (Georgiev et al., 2005, 2007). Thus, these cestodes constitute an important fraction of the total invertebrate diversity in these systems.

\section{(2) Bioindicators}

When species act as bioindicators of the general ecological status of an ecosystem, they can provide a low-cost shortcut for monitoring, for example in sparsely populated regions and in protected areas where monitoring is a priority but funds are limited. Waterbirds have the advantage that they are easy to count and attractive to large parts of the human population, such that long-term datasets on waterbird communities often exist in the absence of historical data on other aquatic organisms (e.g. Rendón et al., 2008). Some waterbirds can serve as good indicators of aquatic biodiversity (Amat \&
Green, 2010). For example, fluctuations in abundance of ducks and coot can accurately indicate changes in the abundance of submerged macrophytes (Wicker \& Endres, 1995), which themselves have a highly positive influence on aquatic diversity (Carpenter \& Lodge, 1986). The crested coot Fulica cristata can be a good indicator of high species richness of aquatic plants (Green et al., 2002a).

At a wetland level, the number of species of breeding dabbling ducks can be a good indicator of the structural diversity of aquatic vegetation [based on a principal components analysis (PCA) of the cover, height and heterogeneity of emergent vegetation and the extent of floating vegetation] as well as of overall abundance of benthic and emerging invertebrates (Elmberg et al., 1993). Even the behaviour of waterfowl can serve as a bioindicator; the degree of pair formation by adults early in the breeding season as well as foraging behaviour in ducklings later in the season correlate with nutrient status (total $\mathrm{P}$ ) in boreal lakes (Nummi et al., 2000; Pöysä et al., 2001). At the other extreme, the absence of breeding common species (e.g. mallard Anas platyrhynchos and Eurasian teal Anas crecca) from seemingly suitable wetlands in Scandinavia indicates very low abundance of invertebrates (Gunnarsson et al., 2004), but not necessarily low primary productivity.

Waterbirds can also be used to assess crudely the fish community of lakes and wetlands in a manner that saves time and money. For example, over large areas red-throated diver Gavia stellata and Slavonian grebe Podiceps auritus almost never nest in lakes holding fish, and there is a strong negative correlation between overall species richness of breeding ducks and occurrence of fish in boreal lakes (e.g. Elmberg, Dessborn \& Englund, 2010; Dessborn, Elmberg \& Englund, 2011b). The distribution of breeding great northern divers $G$. immer is strongly related to a combination of the size of lakes and their 
fish production (Kerekes, 2008). Despite the ease with which waterbirds can be used to obtain important information about wetland ecosystems, their possible role as early warning indicators for regime shifts sensu Carpenter et al. (2011) remains an area for future research. Waterbird feathers and other tissues can also be very useful as biomonitors of heavy metals and other contaminants (Fasola, Movalli \& Gandini, 1998; Taggart et al., 2006; Burger \& Eichhorst, 2007).

However, despite the above examples, waterbirds are not always effective bioindicators. At least in Mediterranean systems, waterbirds sometimes perform poorly as bioindicators compared with taxa more directly affected by water quality, such as submerged vegetation or aquatic invertebrates. Many ducks seem to be sufficiently plastic in their habitat requirements to maintain wintering populations despite ecological change in wetlands (Tamisier \& Grillas, 1994). In contrast to negative correlations found for mammal and fish species richness, Ghermandi et al. (2008) showed in a meta-analysis that wetland degradation had no significant impact on waterbird species richness. Similarly, waterbirds have increased in abundance in many Mediterranean wetlands since 1970 despite wetland degradation that has caused declines in amphibians, reptiles, mammals and fish (MWO, 2012). These positive trends for birds seem to be related to a reduction in hunting pressure, the decreasing impacts of DDT and other banned pesticides, and the ability of many waterbirds to exploit artificial habitats such as ricefields or fish farms that have replaced more natural wetlands (Rendón et al., 2008). Overall, more research is needed to clarify under what circumstances waterbirds are reliable bioindicators, and how this relates to trophic status of the wetlands, to latitude or to different stages of the annual cycle (e.g. are breeding birds better bioindicators than wintering communities?).

\section{(3) Disease surveillance}

Waterbirds are hosts and vectors for a wide range of pathogens, those endemic for birds as well as zoonotic types potentially affecting humans (e.g. Wobeser, 1997; Hubalek, 2004). These negative effects are described well elsewhere and not the subject of our review, but on the flip side the same host-pathogen systems can be used to help monitor pathogens, and waterbirds thereby aid in disease control. Wild migratory ducks have been used successfully to monitor temporal variation in prevalence of subtypes of avian influenza virus (AIV) (Wallensten et al., 2007), which is a useful tool to predict risk of outbreaks of highly pathogenic (HPAIV) variants with the potential to cause huge economic loss to the poultry industry and also epidemics or pandemics in humans (Munster et al., 2005). For example, the HPAIV strain that killed a large number of poultry and even led to a human death in the Netherlands in 2003 was detected in wild mallards shortly before at an upstream site in the same flyway. Moreover, a recent study shows that wild ducks can be used to address spatial patterns of pathogens and infections; by combining AIV screening with ringing recoveries and isotope analysis of feathers grown in natal areas, Gunnarsson et al.
(2012) found evidence that wild transient migrant mallards carry different subtypes of the virus from different source areas. This provides evidence that wild waterbirds can be used to make inferences about the geographical source of disease outbreaks, a research field likely to develop strongly in the near future (Le Comber \& Stevenson, 2012). Finally, captive or non-migratory wild ducks that are allowed to come into contact with wild waterbirds can be used as sentinels and early warning systems to monitor local infection dynamics of a wide range of pathogens (e.g. Ziegler et al., 2010; Farnsworth et al., 2012; Rollo et al., 2012).

\section{(4) Scavengers}

In historical times when they were more abundant, greater adjuntant storks Leptoptilos dubius (now globally threatened) used to dispose of human corpses in India (del Hoyo, Elliot \& Christie, 1992). However, with the possible exception of this species and the congeneric marabou stork L. crumeniferus (Kahl, 1966; del Hoyo et al., 1992), the waterbirds do not include obligate scavengers comparable to vultures. Many other waterbirds are facultative scavengers, and gulls, storks and ibises form large concentrations at rubbish dumps where they scavenge from human waste. Although there may be important negative consequences of this activity (Whelan et al., 2008), it can provide local benefits for neighbouring human populations since it is likely to reduce the smell associated with decomposition of waste by bacteria in the absence of consumption by birds. In addition, birds are likely to remove nutrients from highly impacted sites like dumps and sewagetreatment plants by defecating elsewhere, for example at night roosts. The ecological and sociological consequences of such nutrient movement deserve more research.

\section{(5) Nutrient and biogeochemical cycling}

The great historical economic significance of seabird guano as a source of fertilizer was reviewed by Hutchinson (1950) and Whelan et al. (2008). When moving and forming aggregations, waterbirds automatically influence nutrient fluxes (Figs 3,5). When forming concentrations at roosting sites or in breeding colonies, waterbirds can import enough nutrients to cause major shifts in the trophic status of wetlands. In arctic and other natural landscapes, nutrients are often limiting and guanotrophication can have positive effects on diversity and productivity (Van Geest et al., 2007; Michelutti et al., 2009). Wetland productivity and fish production are likely to be enhanced by the input of nutrients to oligotrophic systems by colonial waterbirds, in a manner similar to the proposed role of hippopotamuses Hippopotamus amphibius in promoting productivity in the Okavango, where they feed on land and then defecate in the water (Mosepele et al., 2009). In Hungarian soda pans the external nutrient loading by geese and other waterbirds provides $50 \%$ of carbon, 70\% of phosphorus and the basis for high production of fairy shrimps and other crustaceans (Boros et al., 2008a, b). However, as eutrophication due to modern agricultural or urban activities in a catchment frequently leads to an excess 
of nutrients in human-modified landscapes, these inputs from birds now often have negative effects in lakes, such as a shift from a clear-water macrophyte state to a turbid, phytoplankton-dominated state (Moss \& Leah, 1982).

Waterbirds such as gulls, storks, geese, swans, and some shorebirds typically feed in both aquatic and terrestrial systems, e.g. at different times of the day or year. They are thus frequently involved in cross-habitat subsidies of energy and nutrients between strictly aquatic and terrestrial systems. Waterbird breeding colonies in forests provide major subsidies through their faeces (Kameda et al., 2006). Such reciprocal subsidies are as yet poorly understood and are currently subject to growing research (Baxter et al., 2004; Burdon \& Harding, 2008).

Apart from simply moving nutrients around as faeces, waterbirds have more subtle and unexpected influences on nutrient and other biogeochemical cycles. Breeding colonies can have a major influence on soil chemistry and cycling of nitrogen and other elements (Ligeza \& Smal, 2003). Goose grazing can promote nitrogen cycling in saltmarshes (Cargill \& Jefferies, 1984; Ruess, Hik \& Jefferies, 1989). Trampling by ducks foraging in ricefields after harvest can increase decomposition of residual surface straw by up to $78 \%$, providing a clear benefit to farmers who otherwise spend up to $\$ 125 \mathrm{ha}^{-1}$ in chopping, ploughing or disking residual rice straw (Bird, Pettygrove \& Eadie, 2000; van Groenigen et al., 2003). Bioturbation by swans feeding on submerged macrophytes can reduce production of methane, a powerful greenhouse gas, owing to increased oxidation of sediments (Bodelier et al., 2006). However, the opposite occurs when waterbirds feed on helophytes (emergent plants) (Dingemans, Bakker \& Bodelier, 2011).

\section{(6) Pest control}

Waterbirds are major predators of aquatic insect larvae and can cause reductions in the abundance of larvae of Chironomidae (non-biting midges) (Sánchez, Green \& Alejandre, 2006; Rodriguez-Perez, Green \& Figuerola, 2007). Chironomids can be economic pests in ricefields, waste-treatment wetlands and elsewhere (Ali, 1996). Waterbirds may also have a role in controlling mosquitoes which are well known as major pests and vectors of disease. Mosquito larvae can comprise a large part of the diet of ducklings (Miles et al., 2002), and are also consumed by terns and shorebirds (Tucakov \& Puzovic, 2006; Fonteneau et al., 2009). However, we are not aware of any studies quantifying the influence that waterbirds have on the abundance of these or other biting dipterans. We suspect this may be substantial, especially in shallow habitats lacking fish but frequented by birds.

Zebra mussels Dreissena polymorpha are highly invasive and have a great economic and ecological impact on invaded lakes and reservoirs in Europe and the Americas. In the USA alone, the damages and associated control costs were estimated at $\$ 1$ billion/year (Pimentel, Zuniga \& Morrison, 2005). Exclosure experiments have shown that diving ducks often greatly reduce the abundance of these bivalves in shallow areas (Hamilton, Ankney \& Bailey, 1994; Werner et al., 2005). Eurasian coots Fulica atra also feed actively on the mussels and seem to prevent greater colonization of boats, associated infrastructure and floating vegetation in shallow invaded systems, all of which are likely to reduce the economic costs of the invasion (G. van der Velde, personal communication).

Waterbirds are also valuable for biological control of snails that eat rice plants (Yusa, Sugiura \& Wada, 2006). Teo (2001) found that a density of 5-10 domestic ducks per hectare reduced the density of golden apple snail Pomacea canaliculata, a major rice pest, by more than 80\%. In northern Europe, domestic and wild ducks are seen as an effective means of reducing numbers of slugs, including the highly invasive Spanish slug Arion vulgaris (Grimm, Paill \& Kaiser, 2000; Speiser et al., 2001).

Many waterbirds such as storks, ibises, egrets and gulls forage extensively in both aquatic and terrestrial habitats and are likely to be important as control agents of agricultural pests. Red-swamp crayfish Procambarus clarkii are a widespread exotic species and major pest in ricefields in California and the Iberian Peninsula, causing significant damage to the seeds and seedlings (Anastacio, Parente \& Correia, 2005) as well as to dykes by digging burrows. Wading birds such as storks, herons and ibises are important predators of these crayfish (Negro et al., 2000; Tablado et al., 2010). Similarly, tadpole shrimps Triops spp. are pests of rice and are depredated by herons (Hafner \& Britton, 1983).

Fish have been widely introduced into waterbodies where they are not native, and their activity can often have a strong negative effect on water quality, e.g. by destroying macrophytes, increasing phosphorous load, or depredating larger zooplankton that are particularly efficient at feeding on phytoplankton (Starling et al., 2002; Søndergaard et al., 2008; Weber \& Brown, 2009). Waterbirds can often be effective predators on fish populations, especially in relatively shallow waterbodies (Britton \& Moser, 1982; Winfield, 1990; Gawlik, 2002; Steinmetz, Kohler \& Soluk, 2003). Owing to the fear of predation, the presence of fish-eating birds can also have indirect effects that can be more important than their direct effects (Fig. 5). Perceived risk of predation affects fish behaviour and growth rates (Allouche \& Gaudin, 2001; Wacht-Katz et al., 2010), and leads them to avoid surface layers and shallow littoral zones during the daytime where they would be visually exposed to piscivorous birds (Gliwicz \& Jachner, 1992; Lewin, Okun \& Mehner, 2004, Mehner, Kasprzak \& Holker, 2007). Thus, the fear of predation by birds can have dramatic cascade effects on food webs in aquatic ecosystems. Although there has been little research on this to date, an outstanding example is the bands of algae in the shallows of tropical streams that result from reduced grazing by catfish seeking to avoid herons and kingfishers (Power, Dudley \& Cooper, 1989).

Massive fish mortalities are often recorded in association with heat waves, droughts and pollution events, and have a highly negative effect on water quality in the areas affected (Kushlan, 1974; Hoyer et al., 2009). However, 


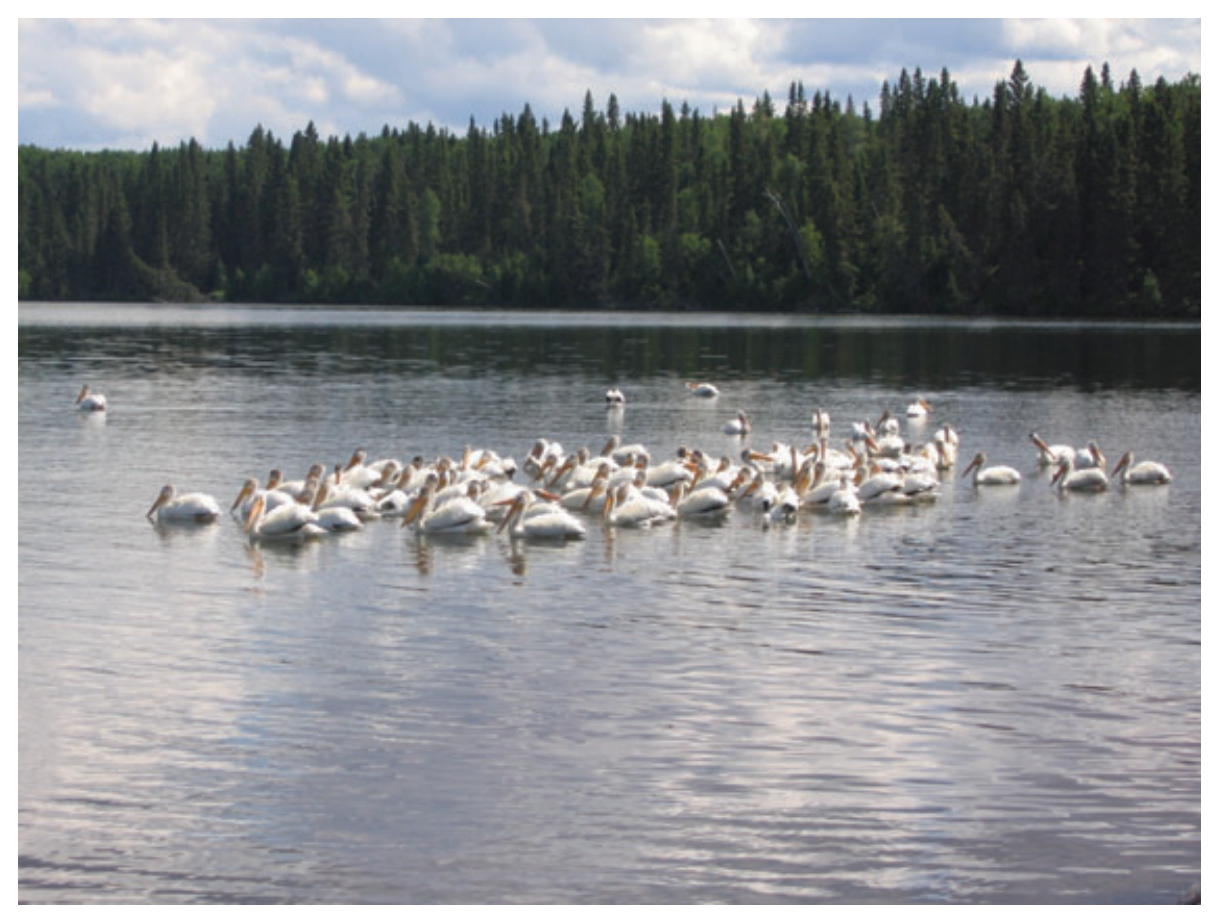

Fig. 5. American white pelicans Pelecanus erythrorhynchos in Prince Albert National Park, Canada. Piscivorous waterbirds can reduce the impact of fish on the diversity of invertebrates by reducing fish activity owing to the fear of predation. They can also control the populations of undesirable, alien fish. Colonial waterbirds such as pelicans also provide important subsidies of nutrients to terrestrial areas where they breed. Photograph: Andy J. Green.

such events might be more frequent were it not for the influence of piscivorous birds. For example, herons, storks, ibises and other wading birds are able to significantly reduce fish populations from waterbodies as water levels decrease during dry periods (Kushlan, 1976; Gawlik, 2002), thus avoiding synchronous fish mortalities and effectively removing nutrients en masse from those wetlands. This in turn may help to reduce outbreaks of toxic cyanobacteria associated with hypertrophy, as well as the anoxia events and disease outbreaks that result from large quantities of fish decomposing. In experimental ponds in the Everglades, after 12 days birds had removed all fish in ponds of $10 \mathrm{~cm}$ depth, and over $50 \%$ of fish in ponds of $28 \mathrm{~cm}$ depth (Gawlik, 2002).

Biomanipulation projects are often launched to improve water quality by controlling fish populations, e.g. by removing cyprinids and introducing piscivorous fish (Jeppesen et al., 2007). It is possible that many shallow lakes do not reach a critical condition where such expensive remediation is necessary because of the direct and indirect influence of waterbirds on fish activity. For example, there is evidence that cormorants increase water transparency owing to their control of benthivorous fish (Leah, Moss \& Forest, 1980; Dirksen et al., 1995). However, effects of birds on fish have rarely been quantified in detail, even in the case of perceived conflicts between birds and economically valuable fish stocks, owing especially to lack of information as to whether or not predation by birds is additive to other sources of mortality in fish populations (Harris et al.,
2008). In one relatively detailed study in a Scottish fishery, cormorants were estimated to remove $40 \%$ of the rainbow trout Oncorhyncus mykiss catch, and 16 times the brown trout Salmo trutta catch (Stewart et al., 2005).

Anatidae are major consumers of seeds of weeds in ricefields, and may provide a significant economic benefit by reducing the abundance of such seeds. The wintering of ducks in flooded ricefields can reduce the biomass of weeds in the following growing season by more than 50\% (van Groenigen et al., 2003). Wintering Anatidae typically frequent ricefields after the rice harvest, and thus do not entail an economic cost owing to loss of rice grain before harvest. On the other hand, as they are good vectors of dispersal, ducks can also promote the spread of weeds (Brochet $e t$ al., 2009). Future research should examine and evaluate the costs and benefits of granivory by waterbirds in ricefields and other agricultural systems.

As well as controlling pests directly by predation, waterbirds can also do so indirectly by spreading parasites that infect pests and reduce their abundance. For example, terns are final hosts for trematode parasites that use mosquitoes as intermediate hosts (Fonteneau et al., 2009). Cestodes that use piscivorous birds as final hosts can reduce the abundance of introduced cyprinids (Kennedy, Shears \& Shears, 2001). Since the life cycle of most helminth parasites remains unknown (Lefebvre et al., 2009) (see also https://web2.uconn.edu/tapeworm/index.php), birds are likely to carry many more parasites of pests than is currently known. 


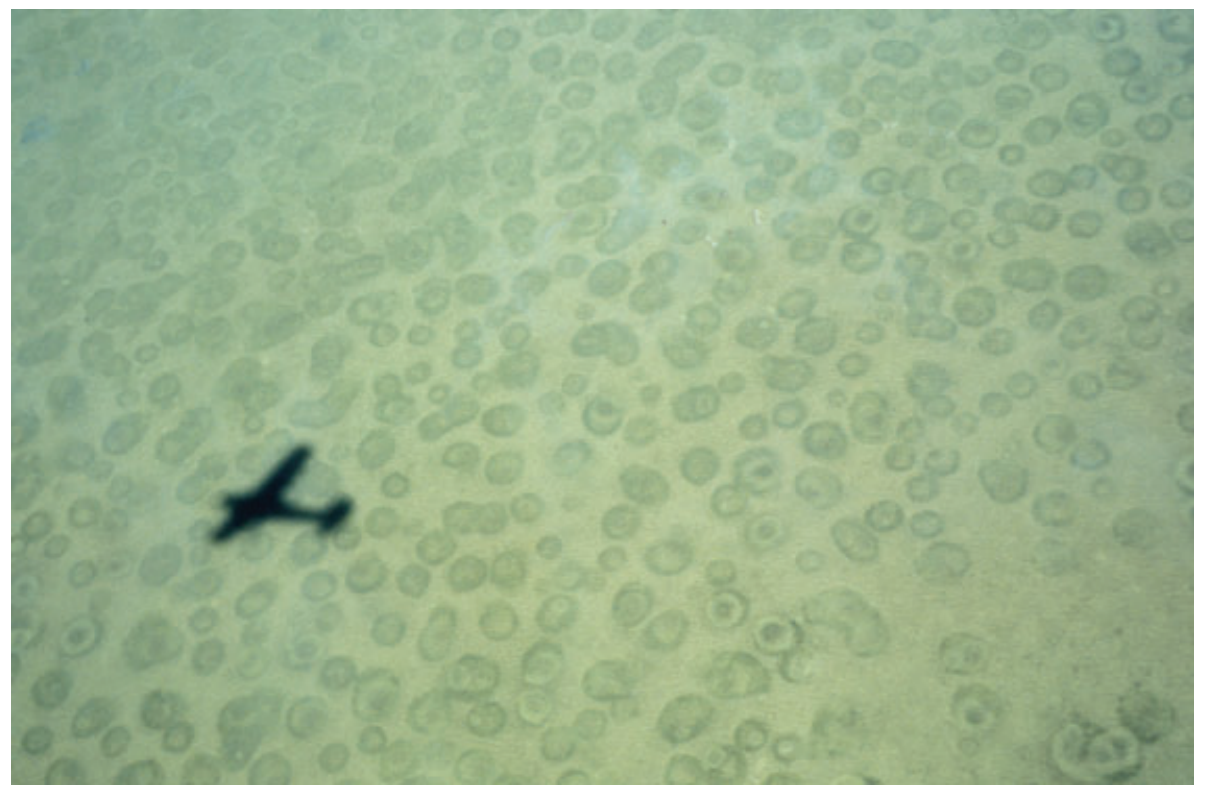

Fig. 6. Craters in soft sediments created by a flock of feeding greater flamingoes flushed by a plane used to count waterbirds in south-west Spain, illustrating the capacity of large waterbirds to act as ecological engineers. Photograph: Hector Garrido.

\section{(7) Ecosystem engineering}

To date the role of waterbirds as ecosystem engineers has largely been ignored and is in need of more research effort. Large birds such as swans or flamingoes have major bioturbation effects when feeding, and can radically change the distribution of sediments (Glassom \& Branch, 1997; Rodríguez-Pérez \& Green, 2006; Sandsten \& Klaassen, 2008; Scott, Renaut \& Owen, 2012; Fig. 6). This may have negative effects on some submerged macrophytes (Sandsten \& Klaassen, 2008), but by increasing spatial heterogeneity this may have as yet unstudied benefits for annelids, dipteran larvae or other organisms exploiting the benthic environment (see Reise, 2002, for such bioturbation benefits in the marine environment). Bioturbation of this kind can also influence aquatic plant communities in subtle ways, and grazing by swans on tubers can promote spatial complexity and species diversity in such communities (Sandsten \& Klaassen, 2008). It has been proposed that shorebirds increase the stability of sediments in the tidal zone, through their predation of amphipods which in turn feed on diatoms that produce carbohydrates that induce sediment cohesion (Daborn et al., 1993). However, experimental evidence for such a cascading effect on mudflat stability is lacking (Hamilton, Diamond \& Wells, 2006).

Colonial waterbirds can have profound effects on the vegetation where their colonies are situated (Telfair \& Bister, 2004; Kolb, Jerling \& Hambäck, 2010), and in dense woodland or reedbeds they open up spaces that increase spatial diversity and provide microhabitats suitable for other species. In many cases, openings in reedbeds are vital for aquatic invertebrates, other aquatic plants, fish and other waterbirds (Murkin, Kaminski \& Titman, 1982; Wagner \& Hansson, 1988; Murkin, Murkin \& Ball, 1997).

\section{(8) Dispersal of seeds, invertebrates and non-pathogenic microbes}

Seed dispersal has been considered as the most important avian ecosystem service provided by terrestrial birds (Sekercioglu, 2006). The great majority of seed dispersal literature focuses on dispersal of plants with fleshy fruits by terrestrial birds, and much less attention has been paid to dispersal of other plants by aquatic birds. Around 36\% of 135 extant families of terrestrial birds are partly or predominantly frugivorous (Herrera, 2002), but this does not include the Anatidae, rails, shorebirds or other aquatic birds as dispersers of seeds from plants lacking fleshy fruits (Green, Figuerola \& Sánchez, 2002b). Likewise, when Wenny et al. (2011) stated that nearly $33 \%$ of bird species disperse seed through fruit consumption and scatter-hoarding of nuts and conifer seed crops, they did not include the dispersal of other seeds by waterbirds. Indeed, one of the conclusions of their review was that (in the context of ecosystem services) 'dispersal of aquatic plants by waterfowl has not been addressed'. In fact, considerable progress has been made in our understanding of seed dispersal by waterbirds over the past decade, but the number of studies is still limited. For example, we are not aware of a single non-anecdotal study of dispersal of seeds or invertebrates by waterbirds in Africa or Asia (but see Aoyama, Kawakami \& Chiba, 2012, for seabirds).

Whereas terrestrial birds are not generally known to act as vectors for invertebrates other than their own parasites and commensalists (but see Wada, Kawakami \& Chiba, 2012, for snails), waterbirds are now known to be vectors of a whole range of aquatic invertebrates, including crustaceans, bryozoans, dipterans, molluscs, rotifers and annelids (Green \& Figuerola, 2005; Frisch, Green \& Figuerola, 2007). Many of these organisms are incapable 
of moving between lakes or river catchments of their own accord, and are too large to disperse effectively by wind, making waterbirds the most important vectors that ensure maintenance of metacommunities and gene flow among populations (Figuerola, Green \& Michot, 2005). Like seeds, invertebrates are dispersed both within the digestive tract of waterbirds and by sticking to feathers, feet and bills, although the former means is most common (Brochet et al., 2010; Sánchez et al., 2012). In addition, waterbirds act as vectors for microbes such as phytoplankton, diatoms, ciliates and the spores of bacteria, archaea and fungi (Schlichting, 1960; Thornton, 1971; Figuerola \& Green, 2002; Green et al., 2008; Brito-Echeverria et al., 2009), although our current understanding of the importance of their role compared to other dispersal modes such as wind is extremely limited (Wilkinson et al., 2012). Furthermore, waterbirds can disperse parasites of other organisms which lack their own means of moving between catchments (Green et al., 2013).

In many cases, keystone species in aquatic systems are themselves dependent on birds for their dispersal. Besides macrophytes, these include crustaceans such as Daphnia spp. or Artemia spp. (Frisch et al., 2007; Sánchez et al., 2007) that are dominant zooplankters regulating phytoplankton abundance and maintaining ecosystems in a clear-water, high-biodiversity state (Wurtsbaugh, 1992; Scheffer, 2001) more likely to provide services for humans compared to a turbid, low-biodiversity state. Indeed, Artemia spp. are considered essential to ensure high-quality brine for salt production (Amat et al., 2005). On the other hand, waterbirds are also vectors for invasive species of invertebrates, promoting their expansion within the introduced range (Green \& Figuerola, 2005; Green et al., 2005).

By acting as vectors of passive dispersal, waterbirds play a vital role in maintaining connectivity among communities in isolated aquatic systems, and thus in maintaining species and genetic diversity (Amezaga, Santamaria \& Green, 2002). Janzen (1984) proposed that waterfowl are now the principal vectors for marshland plants originally dispersed by large, migratory mammals that are now extinct. They also enable rapid migrations of plants and invertebrates required to compensate for climate change (Brochet et al., 2009). The latter is already affecting migratory behaviour of waterbirds (Sauter, Korner-Nievergelt \& Jenni, 2010), thus changing their role as propagule dispersers and, for example, enabling colonization of polar regions by new plant species (Klein et al., 2008).

Anatidae and other waterbirds play a vital role in the colonization and regeneration of new and restored wetlands by aquatic flora and fauna. Tens of thousands of plant and invertebrate species are likely to benefit from dispersal via waterbirds for colonization of new habitats, directed dispersal to suitable sites, gene flow, enhanced germination and escape from areas of high mortality e.g. owing to predation (Bilton, Freeland \& Okamura, 2001; Frisch et al., 2007; Brochet et al., 2009). Nevertheless, owing to a lack of basic research in this subject to date, it is currently impossible to estimate accurately how many plant and invertebrate species are dispersed by waterbirds and how many waterbird species are effective dispersers for each taxonomic group of propagules. What is clear is that waterbirds disperse many plants that are not strictly aquatic, and that have previously been assumed to disperse by other means (Green et al., 2008; Bruun, Lundgren \& Philipp, 2008; Brochet et al., 2009, 2010). Moreover, the possible role of waterbirds as dispersers of fish and amphibians, e.g. by adhesion of eggs or their survival of gut passage as proposed by Wallace (1876), still remains unexplored.

In terrestrial systems, the distances that seeds are dispersed by frugivores are now relatively well studied, but typically are of the order of a few hundred meters (Jordano et al., 2007; Hernández, 201 1). For example, Levey, Tewksbury \& Bolker (2008) consider 'long-distance dispersal' by terrestrial birds to be that over $150 \mathrm{~m}$. By contrast, distances that seeds and eggs are moved by aquatic birds remain unclear and poorly studied, but generally much greater distances can be expected, with maxima of hundreds of kilometers likely for many migratory species (Green et al., 2002b; Figuerola et al., 2010; Sánchez et al., 2012; Viana et al., 2013). However, there is an urgent need to integrate new studies of bird movements using the latest global positioning system (GPS) technologies with studies of seed dispersal, to produce accurate seed shadows.

\section{GENERAL DISGUSSION}

We believe this review serves as a valuable first step towards a clearer understanding of the ecosystem services provided by waterbirds. Many of the services identified above (see also Table 1) were reviewed by Wenny et al. (2011) and Whelan et al. (2008) for terrestrial birds. On the other hand, other services considered here (e.g. provisioning services, dispersal of invertebrates, disease surveillance, influence on methane production) were not considered in these previous reviews. In cases where terrestrial birds and waterbirds provide similar services, they are generally in different habitats, so that 'which group is most important?' is not a relevant question. For example, terrestrial birds obviously provide more services in forests, and waterbirds unique services in wetlands.

Working with waterbirds in this field has some major advantages. Researchers have been urged to 'identify and count the organisms and their characteristics that provide services, and determine how changes in these organisms affect service provision' (Luck et al., 2009, p. 225). Waterbirds are much easier to quantify than the vast majority of organisms, and are generally easier than terrestrial birds as they often occur in open, clearly defined spaces. For that reason, and because they are attractive to people, long-term extensive datasets of waterbird counts and trend analyses of individual populations already exist for many parts of the developed world (e.g. U.S. Fish and Wildlife Service, 2012; Wetlands International, 2012). The fact that the study boundary can often be clearly defined at a relatively local scale (e.g. a particular lake) is another advantage. The demand for, and supply of, ecosystem services is most easily quantified at a local scale (Luck et al., 2009). There is also a great deal of existing literature on waterbirds (e.g. on the ecology of 
Holarctic Anatidae), which provides a solid basis for further research and has been very influential in our review. It has been widely recognized that quantifying the contributions of individual species to a service is challenging compared to working with functional guilds (Luck et al., 2009). However, in the case of waterbirds the ease of quantification makes it more practical. We are fortunate in that a great deal is known about the habitat requirements of many waterbird species. This knowledge can enable managers to attract desirable service providers to wetlands, e.g. pest-controlling species to ricefields or dispersers to newly created wetlands.

However, we often lack essential information about the levels of interactions between waterbirds and other aspects of ecosystems, which currently prevents us from formulating both ecological and economic models. One major impediment for service valuation is undoubtedly the high intrinsic temporal and spatial variability in many of the processes that can be considered as an ecosystem service. Even a single waterbird species can feed and behave in very different ways in different ecosystems, changing its interactions such as prey control or propagule dispersal [see e.g. the spatial variation in diet for ducks (Kear, 2005; Dessborn et al., $2011 a)$. Understanding such variability in time and space is vital to the proper accounting of any ecosystem service (Millennium Ecosystem Assessment, 2005). The division of ecological activity of waterbirds into specific services is itself complicated, as many of them are closely interlinked. For example, birds removing alien fish are providing both pest control and biodiversity support. When dispersing seeds, waterbirds are also moving nutrients and parasites with complex life cycles. However, we should not be intimidated by the complexities of these relationships, as in practical terms it is sufficient to identify the service which is of most interest in a particular landscape (e.g. owing to an obvious economic benefit), and to know how to ensure the persistence of the birds providing that service (Luck et al., 2009).

The value of waterbirds for harvest is an example of a direct service. However, the services provided by birds within an aquatic ecosystem are often indirect and exist because bird activities provide links within and among ecosystems and can have large effects on other species. For this reason, birds and their services are usually excluded from economic models that value ecosystems (Wenny et al., 2011). However, accurate valuation of bird services will improve the corresponding models of ecosystem valuation, as well as strengthening bird conservation and ultimately offering benefits to human society. Furthermore, attempts to value waterbird services will further research on many fundamental questions in ecology regarding the functional role of waterbirds in aquatic ecosystems.

A benefit accruing under natural conditions from waterbird activity might become a cost under modern conditions in transformed habitats, e.g. the supply of nutrients to wetlands by waterbirds is less likely to be beneficial in areas with a large human population, owing to widespread anthropogenic eutrophication. Similarly, colonial waterbirds might kill the only remaining trees in highly fragmented forest habitats (Garcia et al., 2011), and in highly invaded ecosystems, the dispersal of alien plants by waterbirds may be of greater significance than the dispersal of native ones. Hence, the same activity by waterbirds (e.g. herbivory or seed dispersal) can provide a beneficial service in some ecosystems but have deleterious effects in others, and it is likely that research is required in a given system to establish whether or not the costs outweigh the benefits.

Both the current ecological and economic crises make it more important for us to identify and quantify the services provided by waterbirds. This can help us to understand how effectively to conserve, manage, restore, and utilize aquatic biodiversity, and how to make a solid economic case to counter proposals for economic development with a harmful impact on ecosystems. Nevertheless, an ecosystem service approach should be used in combination with traditional conservation strategies, as it does not necessarily advocate for the conservation of endangered species or high species richness, and may positively value exotic species (Luck et al., 2009). For example, alien aquatic plants dispersed by waterbirds can also provide services such as improving water quality and clarity.

It is likely that ecosystem services as a concept will become progressively more influential in decision-making in politics as well as in the management of natural and semi-natural landscapes. The concept of 'ecosystem services' has been adopted by many environmentalists (e.g. Juniper, 2013) who see it as a powerful means to get the attention of economists and others who have previously failed to recognize the value of 'nature' or seen it as an impediment to economic growth. However, some environmentalists have objected to the very principle of 'putting a price on nature' (Monbiot, 2012), and there may be a risk that the 'ecosystem service' concept could be misused or hijacked in a manner resembling the misuse of the 'sustainability' concept.

In order to manage the ecosystem services waterbirds provide, we need to develop a better understanding of their underlying functional ecology. We still lack much basic information on the role that waterbirds have in many ecosystem services, but hope to have made important progress by identifying major gaps for future research, e.g. regarding trophic cascades initiated by piscivorous birds or the importance of waterbirds as vectors of non-pathogenic microbes.

More research is required into the functional responses of waterbirds, as it is extremely useful for prediction, e.g. of how pest control or seed dispersal is influenced by changing abundance of pests or seeds. For example, existing work already gives some idea of how ducks should respond to changing densities of weed seeds in ricefields (Arzel et al., 2007; Greer et al., 2009), or how shorebirds should respond to changing densities of invertebrate pests (Goss-Custard et al., 2006). These functional responses can also be applied within individual-based models that could be developed to allow prediction of when birds switch habitats (Stillman \& Goss-Custard, 2010), e.g. when they forage in habitats where a service such as pest control is desirable.

The total number of waterbirds on Earth is in decline, and many waterbird species are threatened with extinction, 
although these declines are more acute in some parts of the world than others (Wetlands International, 2012). This translates into a loss of their positive ecological functions, such that the declining status of waterbirds is likely to have important negative consequences for aquatic ecosystems (Sekercioglu, Daily \& Erlich, 2004). Wetland birds are projected to have higher rates of extinction this century than those frequenting terrestrial habitats (Sekercioglu et al., 2004). This increases the urgency of identifying and quantifying the services that declining waterbird populations provide.

Given that many waterbird species are undergoing rapid declines, it is important to establish how a service such as seed dispersal is affected by the loss or decline of individual species. At the moment it is unclear to what extent different waterbird species overlap in their roles as vectors and how robust this service is to changes in the waterbird community. Thus, a key question for research is how much functional redundancy there is in the provision of services by different species (Kremen, 2005). In general, if different waterbird species provide similar services over space and time, this reduces the impact of disturbance on the service (Winfree \& Kremen, 2009). It is therefore vital to establish whether individual species dominate in a given service. If so, these species can be considered as key service providers, somewhat analagous to keystone species (Luck et al., 2009). Management for service provision must then focus on this species, whose provisioning may be highly sensitive to disturbance.

Thus, to manage ecosystem services, we need to understand how changes in waterbird communities affect the magnitude and stability of services provided, i.e. the extent of resilience to changes in community composition. We might expect that the provision of services is not usually strongly dependent on single species, since waterbird communities typically have clearly defined guilds with several species in each one, with considerable 'within-group redundancy' owing to similar provisioning of services. In such a case, the characterization of ecosystem services is facilitated by the division of the community into functionally similar guilds, which are made up of redundant species but show functional complementarity between guilds (Kremen \& Ostfeld, 2005). For example, herons and dabbling ducks are two guilds likely to provide very different services. But different species in each of these guilds often overlap considerably in foraging ecology, behaviour and hence service provision. Work so far suggests considerable redundancy in seed dispersal by individual dabbling duck species (Green et al., 2002b; Figuerola, Green \& Santamaria, 2003).

\section{TOWARDS A VALUATION OF WATERBIRD SERVIGES}

There is an urgent need to quantify the economic value of the ecosystem services provided by birds (Wenny et al., 2011). Progress has already been made for cultural and provisioning services (Table 2). Although we now know in general the kinds of ecosystem services provided by waterbirds, in many cases we are currently a long way from having enough understanding of their behaviour and ecology to formulate models of ecosystem valuation that allow us to estimate the economic importance of such services. Prior detailed research is essential in these cases before quantifying the values of these ecosystem services becomes possible. In some other cases, we already have much of the ecological knowledge that could readily be applied to a specific case study. In these cases, the valuation itself is the remaining task. However, rather than measure the absolute value of a service, it is only necessary to compare different situations (typically with or without a service) by marginalist valuation (Salles, 2011). Once the value of a service provided by a waterbird species has been calculated for one study area, 'benefit transfer' can allow the application of the results to other areas (Plummer, 2009).

In case studies for pest control or seed dispersal, economic valuation of services provided by terrestrial birds has been successfully carried out (Wenny et al., 2011). By contrast, to our knowledge, there has to date been no ecosystem-services valuation research on such supporting services by waterbirds. In some cases it is easy to imagine how this could be done. The studies of waterfowl in California ricefields (Bird et al., 2000; van Groenigen et al., 2003) are the closest to date, since they quantify the removal of rice straw and weeds by ducks, but do not include a precise economic valuation. As in this case, exclosure experiments might be used to quantify the benefits of the pest-control service provided by waterbirds in other landscapes, just as they have been used to quantify the crop damage caused by some waterfowl (Parrott \& Mckay, 2001; Borman et al., 2002). One way of valuing part of the dispersal service by waterbirds would be to calculate the replacement costs of planting manually the aquatic vegetation, or introducing the zooplankton and other invertebrates which actually become established in created or restored wetlands owing to their arrival via birds. Equally, the costs of replacing dykes that are vital in preventing floods or in containing water in fish ponds and are protected from wave erosion by vegetation brought by birds could readily be estimated. The high quality of waterbird census data can sometimes greatly facilitate quantification of ecosystem services or disservices. In particular, the models of Hahn, Bauer \& Klaassen $(2007,2008)$ provide an excellent tool for straightforward quantification of the amounts of nutrients moved by different waterbird species found in northern Europe based on waterbird counts. These models could be readily adapted for species in other areas, applying the same assumptions.

As explained above, there has been particular progress in the valuation of provisioning services such as waterfowl harvest value (Table 2). Nevertheless, there is a surprising lack of information on the harvest value of waterbirds in Europe, and in principle progress could readily be made in quantifying the benefits of waterbirds as quarry to hunters in many European countries.

Collaboration between ecologists and economists is required so that progress can be made in valuing the services identified above. Other types of transdisciplinary scientific 
approaches are also sorely needed; management policies used for carnivores, ungulates, and wintering geese in northern Europe during the last decades all show that social sciences must have a key role in the process of valuation of ecosystem services, especially to understand stakeholder acceptance and success of management implementation. Recent progress in accounting for services provided by migratory species (Semmens et al., 2011) is important, since many migratory waterbirds crossing natural boundaries are providing services such as propagule dispersal or pest control. For example, ducks controlling pests or removing straw in ricefields in the USA or Japan breed mainly in Canada or Russia, respectively.

\section{GONGLUSIONS}

(1) Wildfowl, shorebirds, gulls, rails, flamingoes and other waterbirds are major players in the theatre of aquatic ecosystems, and provide a range of important ecosystem services (Table 1). 'Cultural services' such as value for human recreation, and 'provisioning services' such as harvest for meat or feathers, have been evident throughout history and continue to be important. Less attention has been paid to 'regulating services' such as pest control, and 'supporting services' such as maintaining connectivity for plants and invertebrates in isolated wetlands by acting as vectors for dispersal, but these are growth areas for recent research.

(2) Owing to their interactions with other organisms, waterbirds can provide clear indirect benefits for human populations, e.g. by consuming invertebrate pests such as golden apple snails or zebra mussels, facilitating the colonization of new or restored wetlands by plants and invertebrates, promoting decomposition of waste rice straw, reducing the incidence of fish die-offs, or providing a cheap and practical means of monitoring the conservation status of different sites.

(3) Waterbirds often have a positive effect on biodiversity in general, e.g. by regulating competition through grazing, by controlling fish populations, by acting as hosts for unique parasites, by cycling nutrients, and by dispersing seeds, invertebrates and microbes. Other ecosystem services waterbirds provide have only recently become apparent (e.g. disease surveillance) or may be unexpected or easily overlooked (e.g. reduced production of the greenhouse gas methane when swans feed on submerged plants).

(4) Economic valuation of ecosystem services by birds is an emerging research field, but is currently in its infancy. There are relatively advanced studies of the income associated with the hunting of ducks and geese, as well as the recreational value of these groups and the value of harvesting their down (Table 2). To date, studies of the extent to which ducks remove weed seeds and invertebrate pests, and accelerate the breakdown of straw in ricefields, come closest to providing a net economic value of the services that waterbirds provide through their general ecological activity.
(5) An ecosystem service approach has great potential as a positive force for management and conservation of waterbirds, especially in areas of high human density and development pressure. Waterbird and wetland ecologists should demand the resources necessary to investigate the ecosystem services provided by waterbirds in more detail, and use the results to inform decision-makers, the general public and wetland managers. Key questions remain, such as the extent to which services are species-specific or provided in a similar way by closely related species in the same guild.

\section{AGKNOWLEDGEMENTS}

Earlier versions of this manuscript were greatly improved following comments by Dan Wenny, Chris Whelan and Eileen Rees. We have been influenced by many others over the years, who have encouraged us to think 'outside the box' regarding what waterbirds do; those who have been particularly influential include Stuart Hurlbert, the late Janet Kear, Brian Moss, Carlos Montes and Luis Santamaría. This study was supported by grant V-205-09 from the Swedish Environmental Protection Agency. We are grateful to contributing photographers for their support.

\section{REFERENCES}

Ali, A. (1996). A concise review of chironomid midges (Diptera: Chironomidae) as pests and their management. Foumal of Vector Ecology 21, 105-121.

Allard, K. \& Gilchrist, H. G. (2002). Kleptoparasitism of herring gulls taking eider eggs by Canada geese. Waterbirds 25, 235-238.

Allouche, S. \& Gaudin, P. (2001). Effects of avian predation threat, water flow and cover on growth and habitat use by chub, Leuciscus cephalus, in an experimental stream. Oikos 94, 481-492.

Amat, J. A. \& Green, A. J. (2010). Waterbirds as bioindicators of environmental conditions. In Conservation Monitoring in Freshwater Habitats: A Practical Guide and Case Studies (eds C. Hurford, M. Schneider and I. Cowx), pp. 45-52. Springer, Dordrecht.

Amat, F., Hontoria, F., Ruiz, O., Green, A. J., Sánchez, M. I., Figuerola, J. \& Hortas, F. (2005). The American brine shrimp as an exotic invasive species in the western Mediterranean. Biological Invasions 7, 37-47.

Amezaga, J. M., Santamaria, L. \& Green, A. J. (2002). Biotic wetland connectivity-supporting a new approach for wetland policy. Acta OecologicaInternational fournal of Ecology 23, 213-222.

Anastacio, P. M., Parente, V. S. \& Correia, A. M. (2005). Crayfish effects on seeds and seedlings: identification and quantification of damage. Freshwater Biology 50, 697-704.

Aoyama, Y., Kawakami, K. \& Chiba, S. (2012). Seabirds as adhesive seed dispersers of alien and native plants in the oceanic Ogasawara Islands, Japan. Biodiversity and Conservation 21, 2787-2801.

Arnott, W. G. (2007). Birds in the Ancient World from A to Z. Routledge, Abingdon.

Arzel, C., Guillemain, M., Gurd, D. B., Eimberg, J., Fritz, H., Arnaud, A., Pin, C. \& Bosca, F. (2007). Experimental functional response and inter-individual variation in foraging rate of teal (Anas crecca). Behavioural Processes 75, 66-71.

Baxter, C. V., Fausch, K. D., Muramaki, M. \& Chapman, P. L. (2004). Fish invasion restructures stream and forest food webs by interrupting reciprocal prey subsidies. Ecology 85, 2656-2663.

BAZELY, D. R. \& JefFeries, R. L. (1985). Goose feces - a source of nitrogen for plant-growth in a grazed salt-marsh. Fournal of Applied Ecology 22, 693-703.

BEST, R. J. \& ARCESE, P. (2009). Exotic herbivores directly facilitate the exotic grasses they graze: mechanisms for an unexpected positive feedback between invaders. Oecologia 159, 139-150

Bilton, D. T., Freeland, J. R. \& Okamura, B. (2001). Dispersal in freshwater invertebrates. Annual Review of Ecology and Systematics 32, 159-181. 
Bird, J. A., Pettygrove, G. S. \& Eadie, J. M. (2000). The impact of waterfowl foraging on the decomposition of rice straw: mutual benefits for rice growers and waterfowl. Foumal of Applied Ecology 37, 728-741.

Bodelier, P. L. E., Stomp, M., Santamaria, L., Klaassen, M. \& Laanbroek, H. J. (2006). Animal-plant-microbe interactions: direct and indirect effects of swan foraging behaviour modulate methane cycling in temperate shallow wetlands. Oecologia 149, 233-244.

Borman, M. M., Louhaichi, M., Johnson, D. E., Krueger, W. C., Karow, R. S. \& ThомAs, D. R. (2002). Yield mapping to document goose grazing impacts on winter wheat. Agronomy foumal 94, 1087-1093.

Boros, E., Forro, L., Gere, G., Kiss, O., Voros, L. \& Andrikovics, S. (2008a). The role of aquatic birds in the regulation of trophic relationships of continental soda pans in hungary. Acta Zoologica Academiae Scientiarum Hungaricae 54, 189-206.

Boros, E., Nagy, T., Pigniczki, G., Kotyman, L., Balogh, K. V. \& Voros, L. (2008b). The effect of aquatic birds on the nutrient load and water quality of soda pans in hungary. Acta Zoologica Academiae Scientiarum Hungaricae 54, 207-224.

Brito-Echeverria, J., Lopez-Lopez, A., Yarza, P., ANTon, J. \& Rossello-Mora, R. (2009). Occurrence of Halococcus spp. in the nostrils salt glands of the seabird Calonectris diomedea. Extremophiles 13, 557-565.

Britton, R. H. \& Moser, M. E. (1982). Size specific predation by herons and its effect on the sex-ratio of natural-populations of the mosquito fish gambusia-affinis baird and girard. Oecologia 53, 146-151.

Brochet, A. L., Guillemain, M., Fritz, H., Gauthier-Clerc, M. \& Green, A. J. (2009). The role of migratory ducks in the long-distance dispersal of native plants and the spread of exotic plants in Europe. Ecography 32, 919-928.

Brochet, A. L., Guillemain, M., Fritz, H., Gauthier-Clerc, M. \& Green, A. J. (2010). Plant dispersal by teal (Anas crecca) in the Camargue: duck guts are more important than their feet. Freshwater Biology 55, 1262-1273.

Bruun, H. H., Lundgren, R. \& Philipp, M. (2008). Enhancement of local species richness in tundra by seed dispersal through guts of muskox and barnacle goose. Oecologia 155, 101-110.

Buckeridge, K. M. \& JefFeries, R. L. (2007). Vegetation loss alters soil nitrogen dynamics in an Arctic salt marsh. Fournal of Ecology 95, 283-293.

BuRdon, F. J. \& HARding, J. S. (2008). The linkage between riparian predators and aquatic insects across a stream-resource spectrum. Freshwater Biology 53, 330-346.

Burger, J. \& EichHorst, B. (2007). Heavy metals and selenium in grebe feathers from Agassiz national wildlife refuge in northern Minnesota. Archives of Environmental Contamination and Toxicology 53, 442-449.

CARGILL, S. M. \& JefFERIES, R. L. (1984). The effects of grazing by lesser snow geese on the vegetation of a sub-arctic salt-marsh. Fournal of Applied Ecology 21, 669-686.

Carpenter, S. R., Cole, J. J., Pace, M. L., Batt, R., Brock, W. A., Cuine, T., Coloso, J., Hodgson, J. R., Kitchell, J. F., Seekeli, D. A., Smith, L. \& WeIDEL, B. (2011). Early warnings of regime shifts: a whole-ecosystem experiment. Science 332, 1079-1082.

Carpenter, S. R. \& Lodge, D. M. (1986). Effects of submersed macrophytes on ecosystem processes. Aquatic Botany 26, 341-370.

Carss, D. N. \& Marzano, M. (eds) (2005). Reducing the Conffict Between Cormorants and Fisheries on a Pan-European Scale: REDCAFE - Summary and National Overviewes. CEH Project no.C01749. NERC/Centre for Ecology \& Hydrology. Available at http://nora.nerc.ac.uk/14330/. Accessed 5.12.2012.

Daborn, G. R., Amos, C. L., Brylinsky, M., Christian, H., Drapeau, G., FaAs, R. W., Grant, J., Long, B., Paterson, D. M., Perillo, G. M. E. \& Piccolo, M. C. (1993). An ecological cascade effect: migratory birds affect stability of intertidal sediments. Limnology and Oceanography 38, 225-231.

Daily, G. C., Polasky, S., Goldstein, J., Kareiva, P. M., Mooney, H. A., Pejchar, L., Ricketts, T. H., Salzman, J. \& Shallenberger, R. (2009). Ecosystem services in decision making: time to deliver. Frontiers in Ecology and the Environment 7, 21-28.

Dessborn, L., Brochet, A.-L., Elmberg, J., Legagneux, P., Gauthier-Clerc, M. \& Guillemain, M. (2011a). Geographical and temporal patterns in the diet of pintail Anas acuta, wigeon Anas penelope, mallard Anas platyrhynchos and teal Anas crecca in the western Palearctic. European Fournal of Wildlife Research 57, 1119-1129.

Dessborn, L., Elmberg, J. \& Englund, G. (2011b). Pike predation affects breeding success and habitat selection of ducks. Freshwater Biology 56, 579-589.

Dingemans, B. J. J., Bakker, E. S. \& Bodelier, P. L. E. (2011). Aquatic herbivores facilitate the emission of methane from wetlands. Ecology 92, 1166-1173.

Dirksen, S., Boudewijn, T. J., Noordhuis, R. \& Marteijn, E. G. L. (1995). Cormorants phalacrocorax carbo sinensis in shallow eutrophic fresh-water lakes - prey choice and fish consumption in the non-breeding period and effects of large-scale fish removal. Ardea 83, 167-184.

Doughty, R. W. (1975). Feather Fashions and Bird Preservation: A Study in Nature Protection. University of California Press, Berkeley.

DunN, R. R. (2010). Global mapping of ecosystem disservices: the unspoken reality that nature sometimes kills us. Biotropica 42, 555-557.

Edgell, J. \& Williams, G. (1992). The financial value and economic valuation of goose grazing in the European Community. In Waterforwl and Agriculture: Review and Future Perspective, IWRB Special Publication 21 (eds M. van RoOmEn and J. MADSEN), pp. 79-80. IWRB, Slimbridge.
Elmberg, J., Dessborn, L. \& Englund, G. (2010). Presence of fish affects lake use and breeding success in ducks. Hydrobiologia 641, 215-223.

Elmberg, J., Nummi, P., Pöysä, H. \& SJöberg, K. (1993). Factors affecting species number and density of dabbling duck guilds in northern Europe. Ecography 16, $251-260$.

Fabricius, E. \& Norgren, H. (1987). Lär känna Kandagåsen. Svenska Jägareförbundet [Swedish Sportsmens'Association], Stockholm, [Get to know the Canada Goose; in Swedish].

Farnsworth, M. L., Miller, R. S., Pedersen, K., Lutman, M. W., Swafford, S. R., RigGS, P. D. \& Webb, C. T. (2012). Environmental and demographic determinants of avian influenza viruses in waterfowl across the contiguous United States. Plos ONE 7, e32729.

Fasola, M., Movalli, P. A. \& Gandini, C. (1998). Heavy metal, organochlorine pesticide, and PCB residues in eggs and feathers of herons breeding in northern Italy. Archives of Environmental Contamination and Toxicology 34, 87-93.

Figuerola, J., Charalambidou, I., Santamaria, L. \& Green, A. J. (2010). Internal dispersal of seeds by waterfowl: effect of seed size on gut passage time and germination patterns. Naturwissenschaften 97, 555-565.

Figuerola, J. \& Green, A. J. (2002). Dispersal of aquatic organisms by waterbirds: a review of past research and priorities for future studies. Freshwater Biology $\mathbf{4 7}$, 483-494.

Figuerola, J., Green, A. J. \& Мichot, T. C. (2005). Invertebrate eggs can fly: evidence of waterfowl-mediated gene flow in aquatic invertebrates. American Naturalist $165,274-280$.

Figuerola, J., Green, A. J. \& Santamaria, L. (2003). Passive internal transport of aquatic organisms by waterfowl in Donana, south-west Spain. Global Ecology and Biogeography 12, 427-436.

Fonteneau, F., Paillisson, J. M., Kinsella, J. M., Latraube, F. \& Marion, L. (2009). First description of the helminth community in the Whiskered tern Chlidonias hybrida (Lariforma: Sternidae) in France. Revue D Ecologie-La Terre et la Vie 64, 79-84.

Frisch, D., Green, A. J. \& Figuerola, J. (2007). High dispersal capacity of a broad spectrum of aquatic invertebrates via waterbirds. Aquatic Sciences 69, 568-574.

Fukami, T., Wardle, D. A., Bellingham, P. J., Mulder, C. P. H., Towns, D. R., Yeates, G. W., Bonner, K. I., Durrett, M. S., Grant-Hoffman, M. N. \& Williamson, W. M. (2006). Above- and below-ground impacts of introduced predators in seabird-dominated island ecosystems. Ecology Letters 9, 1299-1307.

Galicia, E. \& Baldassarre, G. A. (1997). Effects of motorized tourboats on the behavior of nonbreeding american flamingos in Yucatan, Mexico. Conservation Biology 11, 1159-1165

Gan, C. E. \& LuZar, E. J. (1993). An Economic Analysis of Waterfowl Hunting in Louisiana. Louisiana State University Agricultural Center, Louisiana Agricultural Experiment Station, Louisiana.

Garcia, L. V., Ramo, C., Aponte, C., Moreno, A., Dominguez, M. T., GomezAparicio, L., Redondo, R. \& Maranon, T. (2011). Protected wading bird species threaten relict centenarian cork oaks in a Mediterranean Biosphere Reserve: a conservation management conflict. Biological Conservation 144, 764-771.

Gascoigne, W. R., Hoag, D., Koontz, L., Tangen, B. A., Shaffer, T. L. \& GLEASON, R. A. (2011). Valuing ecosystem and economic services across land-use scenarios in the Prairie Pothole Region of the Dakotas, USA. Ecological Economics 70, $1715-1725$.

Gauthier, G., Giroux, J. F. \& Lochefort, L. (2006). The impact of goose grazing on arctic and temperate wetlands. Acta Zoologica Sinica 52, 108-111.

GaWLIK, D. E. (2002). The effects of prey availability on the numerical response of wading birds. Ecological Monographs 72, 329-346.

Georgiev, B. B., Sánchez, M. I., Green, A. J., Nikolov, P. N., Vasileva, G. P. \& Mavrodieva, R. S. (2005). Cestodes from artemia parthenogenetica (Crustacea, Branchiopoda) in the odiel marshes, Spain: a systematic survey of cysticercoids. Acta Parasitologica 50, 105-117.

Georgiev, B. B., Sánchez, M. I., Vasilevi, G. P., Nikolov, P. N. \& Green, A. J. (2007). Cestode parasitism in invasive and native brine shrimps (Artemia spp.) as a possible factor promoting the rapid invasion of A-franciscana in the Mediterranean region. Parasitology Research 101, 1647-1655.

Ghermandi, A., Van Den Bergh, J. C. J. M., Brander, L. M., De Groot, H. L. F. \& Dias Nunes, P. A. (2008). The economic value of wetland conservation and creation: a meta-analysis. Fondazione Eni Enrico Mattei Working Papers, 238.

Glassom, D. \& Branch, G. M. (1997). Impact of predation by greater flamingos Phoenicopterus ruber on the meiofauna, microflora, and sediment properties of two southern African lagoons. Marine Ecology Progress Series 150, 1-10.

Gliwicz, Z. M. \& Jachner, A. (1992). Diel migrations of juvenile fish - a ghost of predation past or present. Archiv fir Hydrobiologie 124, 385-410.

Goss-Custard, J. D., West, A. D., Yates, M. G., Caldow, R. W. G., Stillman, R. A., Bardsley, L., Castilla, J., Castro, M., Dierschke, V., Durell, S. E. A. L. D., Eichhorn, G., Ens, B. J., Exo, K. M., Udayangani-Fernando, P. U., Ferns, P. N., Hockey, P. A. R., Gill, J. A., Johnstone, I., KalejtaSummers, B., Masero, J. A., Moreira, F., Nagarajan, R. V., Owens, I. P. F., Pacheco, C., Perez-Hurtado, A., Rogers, D., Scheiffarth, G., Sitters, H., Sutherland, W. J., Triplet, P., Worrall, D. H., Zharikov, Y., Zwarts, 
L. \& Pettifor, R. A. (2006). Intake rates and the functional response in shorebirds (Charadriiformes) eating macro-invertebrates. Biological Revieves 81, 501-529.

Grado, S., Hunt, K., Hutt, C., Santos, X. \& Kaminski, R. (2011). Economic impacts of waterfowl hunting in mississippi derived from a state-based mail survey. Human Dimensions of Wildlife 16, 100-113.

Green, A. J., El Hamzaoui, M., El Agbani, M. A. \& Franchimont, J. (2002a). The conservation status of Moroccan wetlands with particular reference to waterbirds and to changes since 1978. Biological Conservation 104, 71-82.

Green, A. J., Figuerola, J. \& SÁnchez, M. I. (2002b). Implications of waterbird ecology for the dispersal of aquatic organisms. Acta Oecologica-International fournal of Ecology 23, 177-189.

Green, A. J. \& Figuerola, J. (2005). Recent advances in the study of long-distance dispersal of aquatic invertebrates via birds. Diversity and Distributions 11, 149-156.

Green, A. J., Frisch, D., Michot, T. G., Allain, L. K. \& Barrow, W. C. (2013). Endozoochory of seeds and invertebrates by migratory waterbirds in Oklahoma, USA. Limnetica 32, 39-46.

Green, A. J., Jenkins, K. M., Bell, D., Morris, P. J. \& Kingsford, R. T. (2008). The potential role of waterbirds in dispersing invertebrates and plants in arid Australia. Freshwater Biology 53, 380-392.

Green, A. J., Sánchez, M. I., Amat, F., Figuerola, J., Hontoria, F., Ruiz, O. \& Hortas, F. (2005). Dispersal of invasive and native brine shrimps Artemia (Anostraca) via waterbirds. Limnology and Oceanography 50, 737-742.

Greer, D. M., Dugger, B. D., Reinecke, K. J. \& Petrie, M. J. (2009). Depletion of rice as food of waterfowl wintering in the mississippi alluvial valley. Fournal of Wildlife Management 73, 1125-1133.

Grimm, B., Paill, W. \& Kaiser, H. (2000). The “Spanish slug": autecology, predators and wild plants as food plants. Förderungsdienst 48, 11-16.

van Groenigen, J. W., Burns, E. G., Eadie, J. M., Horwath, W. R. \& van KESSEL, C. (2003). Effects of foraging waterfowl in winter flooded rice fields on weed stress and residue decomposition. Agriculture Ecosystems \&O Environment 95, 289-296.

Gunnarsson, G., Elmberg, J., SJöberg, K., Pöysä, H. \& Nummi, P. (2004). Why are there so many empty lakes? Food limits survival of mallard ducklings. Canadian fournal of Zoology 82, 1698-1703.

Gunnarsson, G., Latorre-Margalef, N., Hobson, K. A., van Wilgenburg, S. L., Elmberg, J., Olsen, B., Fouchier, R. A. M. \& Waldenström, J. (2012). Disease dynamics and bird migration - linking Mallards Anas platyrhynchos and subtype diversity of the influenza A virus in time and space. PloS ONE 7(4), e35679.

Hafner, H. \& Britton, R. H. (1983). Changes of foraging sites by nesting little egrets (Egretta garzetta L.) in relation to food supply. Colonial Waterbirds 6, 24-30.

Hahn, S., Bauer, S. \& Klaassen, M. (2007). Estimating the contribution of carnivorous waterbirds to nutrient loading in freshwater habitats. Freshwater Biology 52, 2421-2433.

Hahn, S., Bauer, S. \& KlaAssen, M. (2008). Quantification of allochthonous nutrient input into freshwater bodies by herbivorous waterbirds. Freshwater Biology 53, $181-193$.

Hamilton, D. J., Ankney, C. D. \& Bailey, R. C. (1994). Predation of zebra mussels by diving ducks: an exclosure study. Ecology 75, 521-531.

Hamilton, D. J., Diamond, A. W. \& Wells, P. G. (2006). Shorebirds, snails, and the amphipod (Corophium volutator) in the upper Bay of Fundy: top-down vs. bottomup factors, and the influence of compensatory interactions on mudflat ecology. Hydrobiologia 567, 285-306.

Harris, C. M., Calladine, J. R., Wernham, C. V. \& Park, K. J. (2008). Impacts of piscivorous birds on salmonid populations and game fisheries in Scotland: a review. Wildlife Biology 14, 395-411.

Henderson, J. E., Grado, S. C., Munn, I. A. \& Jones, W. D. (2010). Economic Impacts of Wildlife- and Fisheries-Associated Recreation on the Mississippi Economy: An Input-Output Analysis. Research Bulletin FO429. Forest and Wildlife Research Center, Mississippi State University, Starkville.

Hernández, A. (2011). Internal dispersal of seed-inhabiting insects by vertebrate frugivores: a review and prospects. Integrative Zoology 6, 213-221.

Herrera, C. M. (2002). Seed dispersal by vertebrates. In Plant-Animal Interactions: An Evolutionary Approach (eds C. M. Herrera and O. Pellmyr), pp. 185-208. Blackwell Publishing, Oxford.

Hidding, B., Nolet, B. A., De Boer, T., De Vries, P. P. \& Klaassen, M. (2010). Above- and below-ground vertebrate herbivory may each favour a different subordinate species in an aquatic plant community. Oecologia 162, 199-208.

Hirschfeld, A. \& Heyd, A. (2005). Mortality of migratory birds caused by hunting in Europe: bag statistics and proposals for the conservation of birds and animal welfare. Berichte zum Vogelschutz 42, 47-74.

Hoyer, M. V., Watson, D. L., Willis, D. J. \& Canfield, D. E. Jr. (2009). Fish kills in Florida's canals, creeks/rivers, and ponds/lakes. Fournal of Aquatic Plant Management $47,53-56$.

del Hoyo, J., Elliot, A. \& Christie, D. (1992). Handbook of the Birds of the World: Ostrich to Ducks (Volume 1). Lynx Edicions, Barcelona.

Hubalek, Z. (2004). An annotated checklist of pathogenic microorganisms associated with migratory birds. Fournal of Wildlife Diseases 40, 639-659.
Hutchinson, G. E. (1950). Survey of Contemporary Knowledge of Biochemistry. 3. The Biogeochemistry of Vertebrate Excretion (Volume 96). Bulletin of the American Museum of Natural History, New York.

IACOBELLI, A. \& JeFFERIES, R. L. (1991). Inverse salinity gradients in coastal marshes and the death of stands of salix - the effects of grubbing by geese. Fournal of Ecology 79, $61-73$.

Isaac-Renton, M., Bennett, J. R., Best, R. J. \& Arcese, P. (2010). Effects of introduced Canada geese (Branta canadensis) on native plant communities of the Southern Gulf Islands, British Columbia. Ecoscience 17, 394-399.

Janse, J. H. (1997). A model of nutrient dynamics in shallow lakes in relation to multiple stable states. Hydrobiologia 342, 1-8.

Janzen, D. H. (1984). Dispersal of small seeds by big herbivores - foliage is the fruit. American Naturalist 123, 338-353.

Jasmin, J. N., Rochefort, L. \& Gauthier, G. (2008). Goose grazing influences the fine-scale structure of a bryophyte community in arctic wetlands. Polar Biology 31 , 1043-1049.

Jeppesen, E., Meerhoff, M., Jacobsen, B. A., Hansen, R. S., Søndergaard, M., Jensen, J. P., Lauridsen, T. L., Mazzeo, N. \& Branco, C. W. C. (2007). Restoration of shallow lakes by nutrient control and biomanipulation-the successful strategy varies with lake size and climate. Hydrobiologia 581, 269-285.

Jordano, P., Garcia, C., Godoy, J. A. \& Garcia-Castano, J. L. (2007). Differential contribution of frugivores to complex seed dispersal patterns. Proceedings of the National Academy of Sciences of the United States of America 104, 3278-3282.

Juniper, T. (2013). What Has Nature Ever Done for Us? Profile Books, London.

KAHL, M. P. (1966). A contribution to ecology and reproductive biology of marabou stork (Leptoptilos crumeniferus) in East Africa. Fournal of Zoology 148, 289-311.

Kameda, K., Кова, K., Ноbara, S., Osono, T. \& Terai, M. (2006). Pattern of natural N-15 abundance in lakeside forest ecosystem affected by cormorant-derived nitrogen. Hydrobiologia 567, 69-86.

KEAR, J. (1990). Man and Wildfowl. T \& A.D, Poyser, London.

Kear, J. (2005). Bird Families of the World: Ducks, Geese and Swans. Oxford University Press, Oxford.

Kennedy, C. R., Shears, P. C. \& Shears, J. A. (2001). Long-term dynamics of Ligula intestinalis and roach Rutilus rutilus: a study of three epizootic cycles over thirty-one years. Parasitology 123, 257-269.

Kerekes, J. (2008). Habitat use by breeding common loons (Gavia immer) in the Atlantic region National Parks in Canada. Acta Zoologica Academiae Scientiarum Hungaricae 54(Suppl. 1), 265-269.

Klein, D. R., Bruun, H. H., Lundgren, R. \& Philipp, M. (2008). Climate change influences on species interrelationships and distributions in high-Arctic Greenland. Advances in Ecological Research 40, 81-100.

Kolb, G. S., Jerling, L. \& Hambäck, P. A. (2010). The impact of cormorants on plant-arthropod food webs on their nesting Islands. Ecosystems 13, 353-366.

van Kooten, G. C., Withey, P. \& Wong, L. D. (2011). Bioeconomic modeling of wetlands and waterfowl in western Canada: accounting for amenity values. Canadian Journal of Agricultural Economics-Revue Canadienne d' Agroeconomie 59, 167-183.

Krcmar, E., Van Kooten, G. C. \& Chan-McLeod, A. (2010). Waterfowl Harvest Benefits in Northern Aboriginal Communities and Potential Climate Change Impacts. Resource Economics \& Policy Analysis Research Group, Department of Economics, University of Victoria, Victoria BC.

Kremen, C. (2005). Managing ecosystem services: what do we need to know about their ecology? Ecology Letters 8, 468-479.

Kremen, C. \& OstFeld, R. S. (2005). A call to ecologists: measuring, analyzing, and managing ecosystem services. Frontiers in Ecology and the Environment 3, 540-548.

Kushlan, J. A. (1974). Effects of a natural fish kill on water-quality, plankton, and fish population of a pond in big cypress swamp, Florida. Transactions of the American Fisheries Society 103, 235-243.

Kushlan, J. A. (1976). Wading bird predation in a seasonally fluctuating pond. Auk 93, $464-476$.

Lampert, W. \& Sommer, U. (2007). Limnoecology. Second Edition. Oxford University Press, Oxford.

Leah, R. T., Moss, B. \& Forrest, D. E. (1980). The role of predation in causing major changes in the limnology of a hyper-eutrophic lake. Internationale Revue der Gesamten Hydrobiologie 65, 223-247.

Le Comber, S. C. \& Stevenson, M. D. (2012). From Jack the Ripper to epidemiology and ecology. Trends in Ecology \& Evolution 27, 307-308.

Lefebvre, F., Georgiev, B. B., Bray, R. A. \& Littlewood, D. T. J. (2009). Developing a dedicated cestode life cycle database: lessons from the hymenolepidids. Helminthologia 46, 21-27.

Levey, D. J., Tewksbury, J. J. \& Bolker, B. M. (2008). Modelling long-distance seed dispersal in heterogeneous landscapes. Fournal of Ecology 96, 599-608.

Lewin, W. C., OKun, N. \& Mehner, T. (2004). Determinants of the distribution of juvenile fish in the littoral area of a shallow lake. Freshwater Biology 49, 410-424.

LigezA, S. \& SMAL, H. (2003). Accumulation of nutrients in soils affected by perennial colonies of piscivorous birds with reference to biogeochemical cycles of elements. Chemosphere 52, 595-602.

Losey, J. E. \& Vaughan, M. (2006). The economic value of ecological services provided by insects. Bioscience 56, 311-323. 
Luck, G. W., Harrington, R., Harrison, P. A., Kremen, C., Berry, P. M., Bugter, R., Dawson, T. P., De Bello, F., Diaz, S., Feld, G. K., Haslett, J. R., Hering, D., Kontogianni, A., Lavorel, S., Rounsevell, M., Samways, M. J., Sandin, L., Settele, J., Sykes, M. T., Van Den Hove, S., Vandewalle, M. \& ZовеL, M. (2009). Quantifying the contribution of organisms to the provision of ecosystem services. Bioscience 59, 223-235.

MacMillan, D., Hanley, N. \& Daw, M. (2004). Costs and benefits of wild goose conservation in Scotland. Biological Conservation 119, 475-485.

MacMillan, D. C. \& Leader-Williams, N. (2008). When successful conservation breeds conflict: an economic perspective on wild goose management. Bird Conservation International 18, $\mathrm{S} 200-\mathrm{S} 210$.

Mann, H., Proctor, V. W. \& Taylor, A. S. (1999). Towards a biogeography of north American charophytes. Australian Fournal of Botany 47, 445-458.

Maron, J. L., Estes, J. A., Croll, D. A., Danner, E. M., Elmendorf, S. G. \& Buckelew, S. L. (2006). An introduced predator alters Aleutian Island plant communities by thwarting nutrient subsidies. Ecological Monographs 76, 3-24.

MAs, M. (2000). Proyecto de Investigación Arqueológica. Las Manifestaciones Rupestres Prehistóricas de la zona Gaditana. Junta de Andalucía, Consejería de Cultura, Sevilla.

Mehner, T., Kasprzak, P. \& Holker, F. (2007). Exploring ultimate hypotheses to predict diel vertical migrations in coregonid fish. Canadian Fournal of Fisheries and Aquatic Sciences 64, 874-886.

Michelutti, N., Keatley, B. E., Brimble, S., Blais, J. M., Liu, H. J., Douglas, M. S. V., Mallory, M. L., Macdonald, R. W. \& Smol, J. P. (2009). Seabirddriven shifts in Arctic pond ecosystems. Proceedings of the Royal Society Series B: Biological Sciences 276, 591-596.

Miles, A. K., Lawler, S. P., Dritz, D. \& Spring, S. (2002). Effects of mosquito larvicide on mallard ducklings and prey. Wildlife Society Bulletin 30, 675-682.

Millennium Ecosystem Assessment (MEA) (2005). Ecosystems and Human Well-Being: Synthesis. Island Press, Washington, DC.

Mini, A. E., Bachman, D. C., Cocke, J. \& Black, J. M. (2011). Recovery of the Aleutian Cackling Goose Branta hutchinsii leucopareia: 10-year review and future prospects. Wildfowl 61, 3-29.

Monbiot, G. (2012). Putting a price on the rivers and rain diminishes us all. Guardian, 6th August. Available at http://www.guardian.co.uk/commentisfree/ 2012/aug/06/price-rivers-rain-greatest-privatisation?intcmp $=239$

MoorJ, J. H. (2005). Protection and use of waterbirds in the European Union. Beiträge zurfagd- und Wildforschung 30, 49-76.

Mooij, W. M., Janse, J. H., Domis, L. N. D. S., Hulsmann, S. \& Ibelings, B. W. (2007). Predicting the effect of climate change on temperate shallow lakes with the ecosystem model PCLake. Hydrobiologia 584, 443-454.

Mosepele, K., Moyle, P. B., Merron, G. S., Purkey, D. R. \& Mosepele, B. (2009). Fish, floods, and ecosystem engineers: aquatic conservation in the okavango delta, Botswana. Bioscience 59, 53-64.

Moss, B. \& LeAH, R. T. (1982). Changes in the ecosystem of a guanotrophic and brackish shallow lake in Eastern England - potential problems in its restoration. Internationale Revue der Gesamten Hydrobiologie 67, 625-659.

Munster, V. J., Wallensten, A., Baas, C., Rimmelzwaan, G. F., Schutten, M., Olsen, B., Osterhaus, A. D. M. E. \& Fouchier, R. A. M. (2005). Mallards and highly pathogenic avian influenza ancestral viruses, northern Europe. Emerging Infectious Diseases 11, 1545-1551.

Murkin, H. R., Kaminski, R. M. \& Titman, R. D. (1982). Responses by dabbling ducks and aquatic invertebrates to an experimentally manipulated cattail marsh. Canadian Foumal of Zoology 60, 2324-2332.

Murkin, H. R., Murkin, E. J. \& Ball, J. P. (1997). Avian habitat selection and prairie wetland dynamics: a 10-year experiment. Ecological Applications 7, 1144-1159.

MWO (2012). Mediterranean Wetlands: outlook. First Mediterranean Wetlands Observatory report. Technical report, Tour du Valat, Le Sambuc, France.

NACKEN, N. \& ReISE, K. (2000). Effects of herbivorous birds on intertidal seagrass beds in the northern Wadden Sea. Helgoland Marine Research 54, 87-94.

Nakano, S. \& Murakami, M. (2001). Reciprocal subsidies: dynamic interdependence between terrestrial and aquatic food webs. Proceedings of the National Academy of Sciences of the United States of America 98, 166-170.

Negro, J. J., Tella, J. L., Blanco, G., Forero, M. G. \& Garrido-Fernández, J. (2000). Diet explains interpopulation variation of plasma carotenoids and skin pigmentation in nestling white storks. Physiological and Biochemical Zoology 73, 97-101. vaN Nes, E. H., RIP, W. J. \& SCHEFFER, M. (2007). A theory for cyclic shifts between alternative states in shallow lakes. Ecosystems 10, 17-27.

NOLET, B. A. (2004). Overcompensation and grazing optimisation in a swan-pondweed system? Freshwater Biology 49, 1391-1399.

Nummi, P., SJöberg, K., Pöysä, H. \& Elmberg, J. (2000). Individual foraging behaviour indicates resource limitation: an experiment with mallard ducklings. Canadian Foumal of Zoology 78, 1891-1895.

Parrott, D. \& McKay, H. V. (2001). Mute swan grazing on winter crops: estimation of yield loss in oilseed rape and wheat. Crop Protection 20, 913-919.

Pimentel, D., Zuniga, R. \& Morrison, D. (2005). Update on the environmental and economic costs associated with alien-invasive species in the United States. Ecological Economics 52, 273-288.
Plummer, M. L. (2009). Assessing benefit transfer for the valuation of ecosystem services. Frontiers in Ecology and the Environment 7, 38-45.

Power, M. E., Dudley, T. L. \& Cooper, S. D. (1989). Grazing catfish, fishing birds, and attached algae in a panamanian stream. Environmental Biology of Fishes 26, 285-294.

Pöysä, H., SJöberg, K., Elmberg, J. \& Nummi, P. (2001). Pair formation among experimentally introduced mallards Anas platyrhynchos reflects habitat quality. Annales Zoologici Fennici 38, 179-184.

REISE, K. (2002). Sediment mediated species interactions in coastal waters. Foumal of Sea Research 48, 127-141.

Rendón, M. A., Green, A. J., Aquilera, E. \& Almaraz, P. (2008). Status, distribution and long-term changes in the waterbird community wintering in Donana, south-west Spain. Biological Conservation 141, 1371-1388.

Richardson, L. \& Loomis, J. (2009). The total economic value of threatened, endangered and rare species: an updated meta-analysis. Ecological Economics 68, $1535-1548$.

Rodríguez-PÉrez, H. \& Green, A. J. (2006). Waterbird impacts on widgeongrass Ruppia maritima in a mediterranean wetland: comparing bird groups and seasonal effects. Oikos 112, 525-534.

Rodriguez-Perez, H., Green, A. J. \& Figuerola, J. (2007). Effects of greater flamingo Phoenicopterus ruber on macrophytes, chironomids and turbidity in natural marshes in Doñana, SW Spain. Fundamental and Applied Limnology 170, 167-175.

Rollo, S. N., Ferro, P. J., Peterson, M. J., Ward, M. P., Ballard, B. M. \& LuPIANI, B. (2012). Role of nonmigratory mottled ducks (Anas fulvigula) as sentinels for avian influenza surveillance. Fournal of Zoo and Wildlife Medicine 43, 168-170.

Ruess, R. W., Hik, D. S. \& JefFeries, R. L. (1989). The role of lesser snow geese as nitrogen processors in a sub-arctic salt-marsh. Oecologia 79, 23-29.

SALLES, J. M. (2011). Valuing biodiversity and ecosystem services: why put economic values on nature? Comptes Rendus Biologies 334, 469-482.

Sánchez, M. I., Green, A. J. \& Alejandre, R. (2006). Shorebird predation affects density, biomass, and size distribution of benthic chironomids in salt pans: an exclosure experiment. Fournal of the North American Benthological Society 25, 9-18.

Sánchez, M.I., Green, A.J. \& Castellanos, E.M. (2006). Temporal and spatial variation of an aquatic invertebrate community subjected to avian predation at the Odiel salt pans (SW Spain). Archiv fur Hydrobiologie 166, 199-223.

Sánchez, M. I., Green, A. J., Amat, F. \& Castellanos, E. M. (2007). Transport of brine shrimps via the digestive system of migratory waders: dispersal probabilities depend on diet and season. Marine Biology 151, 1407-1415.

Sánchez, M. I., Hortas, F., Figuerola, J. \& Green, A. J. (2012). Comparing the potential for dispersal via waterbirds of a native and an invasive brine shrimp. Freshwater Biology 57, 1896-1903.

Sandsten, H. \& KlaAssen, M. (2008). Swan foraging shapes spatial distribution of two submerged plants, favouring the preferred prey species. Oecologia 156, 569-576.

SaUter, A., Korner-Nievergelt, F. \& Jenni, L. (2010). Evidence of climate change effects on within-winter movements of European Mallards Anas platyrhynchos. Ibis $152,600-609$.

Scheffer, M. (2001). Alternative attractors of shallow lakes. The Scientific World 1, 254-263.

Scheffer, M., Van Geest, G. J., Zimmer, K., Jeppesen, E., Søndergaard, M., Butler, M. G., Hanson, M. A., DeClerck, S. \& De Meester, L. (2006). Small habitat size and isolation can promote species richness: second-order effects on biodiversity in shallow lakes and ponds. Oikos 112, 227-231.

Schlichting, H. E. J. (1960). The role of waterfowl in the dispersal of algae. Transactions of the American Microscopical Society 79, 160-166.

Scott, J. J., Renaut, R. W. \& Owen, R. B. (2012). Impacts of flamingos on saline lake margin and shallow lacustrine sediments in the Kenya Rift Valley. Sedimentary Geology 277-278, 32-51.

Sekercioglu, C. H. (2006). Increasing awareness of avian ecological function. Trends in Ecology \& Evolution 21, 464-471.

Sekercioglu, C. H., Daily, G. C. \& Ehrlich, P. R. (2004). Ecosystem consequences of bird declines. Proceedings of the National Academy of Sciences of the United States of America 101, 18042-18047.

Semmens, D. J., Diffendorfer, J. E., Lopez-Hoffman, L. \& Shapiro, C. D. (2011). Accounting for the ecosystem services of migratory species: quantifying migration support and spatial subsidies. Ecological Economics 70, 2236-2242.

Søndergaard, M., Liboriussen, L., Pedersen, A. R. \& Jeppesen, E. (2008). Lake restoration by fish removal: short- and long-term effects in 36 danish lakes. Ecosystems 11, 1291-1305.

Speiser, B., Glen, D., Piggot, S., Ester, A., Davies, K., Castillejo, J. \& Coupland, J. (2001). Slug Damage and Control of Slugs in Horticultural Crops. FiBL-Merkblatt, Research Institute of Organic Agriculture (FiBL), Available at http://orgprints.org/515/1/Slugcontrol.pdf. Accessed 23.07.2012.

Starling, F., Lazzaro, X., Cavalcanti, G. \& Moreira, R. (2002). Contribution of omnivorous tilapia to eutrophication of a shallow tropical reservoir: evidence from a fish kill. Freshwater Biology 47, 2443-2452.

Steinmetz, J., Kohler, S. L. \& Soluk, D. A. (2003). Birds are overlooked top predators in aquatic food webs. Ecology $\mathbf{8 4}, 1324-1328$. 
Stewart, D. C., Middlemas, S. J., Gardiner, W. R., Mackay, S. \& Armstrong, J. D. (2005). Diet and prey selection of cormorants (Phalacrocorax carbo) at Loch Leven, a major stocked trout fishery. Fournal of Zoology 267, 191-201.

Stillman, R. A. \& Goss-Custard, J. D. (2010). Individual-based ecology of coastal birds. Biological Reviewes 85, 413-434.

Sveinsson, J. (2013). Real eiderdown. Available at http://eiderdown.com/ files/eider_article.pdf

Tablado, Z., Tella, J. L., Sanchez-Zapata, J. A. \& Hiraldo, F. (2010). The paradox of the long-term positive effects of a North American crayfish on a European community of predators. Conservation Biology 24, 1230-1238.

Taggart, M. A., Figuerola, J., Green, A. J., Mateo, R., Deacon, C., Osborn, D. \& Meharg, A. A. (2006). After the Aznalcollar mine spill: arsenic, zinc, selenium, lead and copper levels in the livers and bones of five waterfowl species. Environmental Research 100, 349-361.

Tamisier, A. \& Grillas, P. (1994). A review of habitat changes in the Camargue: an assessment of the effects of the loss of biological diversity on the wintering waterfowl community. Biological Conservation 70, 39-47.

Telfair, P. C. \& Bister, T. J. (2004). Long-term breeding success of the cattle egret in Texas. Waterbirds 27, 69-78.

TEo, S. S. (2001). Evaluation of different duck varieties for the control of the golden apple snail (Pomacea canaliculata) in transplanted and direct seeded rice. Crop Protection 20, 599-604.

Thornton, M. L. (1971). Potential for long-range dispersal of aquatic phycomycetes by internal transport in birds. Transactions of the British Mycological Society 57, 49-59.

Tucakov, M. \& Puzovic, S. (2006). Breeding waterbirds on wastewater pools of four sugar refineries in Vojvodina. Natura Croatica 15, 1-14.

U.S. Fish and Wildlife Service (2012). Waterfowl Population Status, 2012. U.S. Department of the Interior, Washington, DC.

Van Geest, G. J., Hessen, D. O., Spierenburg, P., Dahl-Hansen, G. A. P., Christensen, G., Faerovig, P. J., Brehm, M., Loonen, M. J. J. E. \& Van Donk, E. (2007). Goose-mediated nutrient enrichment and planktonic grazer control in arctic freshwater ponds. Oecologia 153, 653-662.

Viana, D. S., Santamaria, L., Michot, T. C. \& Figuerola, J. (2013). Migratory strategies of waterbirds shape the continental-scale dispersal of aquatic organisms. Ecography 36, 430-438.

Wacht-Katz, M., Abramsky, Z., Kotler, B., Altstein, O. \& Rosenzweig, M. L. (2010). Playing the waiting game: predator and prey in a test environment. Evolutionary Ecology Research 12, 793-801.

Wada, S., Kawakami, K. \& Chiba, S. (2012). Snails can survive passage through a bird's digestive system. Fournal of Biogeography 39, 69-73.

Wagner, B. M. A. \& Hansson, L. A. (1988). Food competition and niche separation between fish and the Red-necked Grebe Podiceps grisegena (Boddaert, 1783). Hydrobiologia 368, 75-81.

Wallace, A. R. (1876). The Geographical Distribution of Animals with a Study of the Relations of Living and Extinct Faunas as Elucidating the Past Changes of the Earth's Surface. Macmillan and Co., London.
Wallensten, A., Munster, V. J., Latorre-Margalef, N., Brytting, M., Elmberg, J., Fouchier, R. A. M., Fransson, T., Haemig, P. D., Karlsson, M., Lundkvist, A., Osterhaus, A. D. M. E., Stervander, M., Waldenström, J. \& OLSEN, B. (2007). Surveillance of influenza A virus in migratory waterfowl in northern Europe. Emerging Infectious Diseases 13, 404-411.

Weber, M. J. \& Brown, M. L. (2009). Effects of common carp on aquatic ecosystems 80 years after "Carp as a Dominant": ecological insights for fisheries management Reviews in Fisheries Science 17, 524-537.

Wenny, D. G., Devault, T. L., Johnson, M. D., Kelly, D., Sekercioglu, C. H., Tomback, D. F. \& Whelan, C. J. (2011). The need to quantify ecosystem services provided by birds. Auk 128, $1-14$.

Werner, S., Mortl, M., Bauer, H. G. \& Rothhaupt, K. O. (2005). Strong impact of wintering waterbirds on zebra mussel (dreissena polymorpha) populations at lake Constance, Germany. Freshwater Biology 50, 1412-1426.

Wetlands International (2012). Waterbird Population Estimates. Wetlands International. Available at wpe.wetlands.org Accessed 26.07.2012.

Whelan, G. J., Wenny, D. G. \& Marouise, R. J. (2008). Ecosystem services provided by birds. In The Year in Ecology and Conservation Biology 2008 (Volume 1134, eds R. S. Ostfeld and W. H. Schlesinger), pp. 25-60. Annals of the New York Academy of Sciences, New York.

Wicker, A. M. \& ENDres, K. M. (1995). Relationship between waterfowl and American coot abundance with submersed macrophytic vegetation in Currituck sound, North Carolina. Estuaries 18, 428-431.

Wilkinson, D. M., Koumoutsaris, S., Mitchell, E. A. D. \& Bey, I. (2012). Modelling the effect of size on the aerial dispersal of microorganisms. Fournal of Biogeography 39, 89-97.

Winfield, I. J. (1990). Predation pressure from above - observations on the activities of piscivorous birds at a shallow eutrophic lake. Hydrobiologia 191, 223-231.

Winfree, R. \& Kremen, C. (2009). Are ecosystem services stabilized by differences among species? A test using crop pollination. Proceedings of the Royal Society Series B: Biological Sciences 276, 229-237.

Withey, P. \& Van Kooten, G. C. (2011). The effect of climate change on optimal wetlands and waterfowl management in Western Canada. Ecological Economics 70 , $798-805$.

Wobeser, G. (1997). Diseases of Wild Waterfowl. 2nd Edition. Plenum Press, New York. Wood, K. A., Stillman, R. A., Clarke, R. T., Daunt, F. \& O’Hare, M. T. (2012). The impact of waterfowl herbivory on plant standing crop: a meta-analysis. Hydrobiologia 686, 157-167.

Wurtsbaugh, W. A. (1992). Food-Web modification by an invertebrate predator in The Great-Salt-Lake (USA). Oecologia 89, 168-175.

Yusa, Y., Sugiura, N. \& WAda, T. (2006). Predatory potential of freshwater animals on an invasive agricultural pest, the apple snail Pomacea canaliculata (Gastropoda: Ampullariidae), in southern Japan. Biological Invasions 8, 137-147.

Ziegler, U., Seidowski, D., Globig, A., Fereidouni, S. R., Ulrich, R. G. \& Groschup, M. H. (2010). Sentinel birds in wild-bird resting sites as potential indicators for West Nile virus infections in Germany. Archives of Virology 155 965-969.

(Received 27 September 2012; revised 16 May 2013; accepted 23 May 2013; published online 21 June 2013) 